\title{
Enrollment in Ethiopia’s Community-Based Health Insurance Scheme
}

\author{
ANAGAW D. MEBRATIE ${ }^{\mathrm{a}}$, ROBERT SPARROW ${ }^{\mathrm{b}}$, ZELALEM YILMA $^{\mathrm{a}}$, GETNET ALEMU $^{\mathrm{c}}$ and \\ ARJUN S. BEDI ${ }^{\mathrm{a}, \mathrm{d}, *}$ \\ a Erasmus University Rotterdam, The Hague, The Netherlands \\ ${ }^{\mathrm{b}}$ Australian National University, Canberra, Australia \\ ${ }^{\mathrm{c}}$ Addis Ababa University, Ethiopia \\ ${ }^{\mathrm{d}}$ Georgetown University School of Foreign Service-Qatar, Qatar
}

\begin{abstract}
Summary. - In June 2011, the Ethiopian government launched a Community-Based Health Insurance scheme. By December 2012, enrollment reached $45.5 \%$. This paper examines uptake. Socioeconomic status does not inhibit uptake and food-insecure households are more likely to enroll. Chronic diseases and self-assessed health status do not induce enrollment, while past expenditure does. A relative novelty is the identification of quality of care. Both the availability of equipment and waiting time to see medical professionals substantially influences enrollment. Focus-groups raise concerns about providers favoring uninsured households. Nevertheless, almost all insured households want to renew and majority of uninsured want to enroll.

(c) 2015 Elsevier Ltd. All rights reserved.
\end{abstract}

Key words - Community-Based Health Insurance, adverse selection, social exclusion, Ethiopia, Africa

\section{INTRODUCTION}

Over the past decade, Ethiopia has recorded notable progress in a number of population health outcomes. For instance child mortality per 1,000 live births has fallen from 166 in 2000 to 88 in 2011 and maternal mortality rates have declined from 871 to 676 per 100,000 live births. These changes have been accompanied by a rapid expansion of health-care infrastructure at all levels. According to Ethiopia's Federal Ministry of Health (FMoH, 2011), there has been an 18-fold increase in the number of health posts from 833 in 2000 to 15,095 in 2011 and a sevenfold increase $(356-2,660)$ in the number of health centers over the same period. Consequently it is estimated that primary health care coverage, defined as village-level access to a health post, has increased from $51 \%$ in 2000 to $92 \%$ in 2011 .

Despite these increases in the supply of health care and increases in the utilization of some specific services, overall utilization rates remain low. For example, according to the Ethiopian Demographic and Health Surveys, outpatient health care utilization per capita per year has increased only marginally from 0.27 visits in 2000 to 0.3 visits in 2011. The low utilization rates are accompanied by a high reliance on out-of-pocket (OOP) spending to finance health care. The $\mathrm{FMoH}$ (2010) estimates that the three main sources of health-care financing in Ethiopia are local and international donors $(40 \%)$, out-of-pocket (OOP) spending by health-care users $(37 \%)$, and central and local governments $(21 \%)$. The remainder (about $2 \%$ ) is covered by employer and other private insurance schemes.

Since the late 1990s, Community-Based Health Insurance schemes (CBHI) which involve potential clients in determining scheme benefits and scheme management have been implemented in several developing countries (Dekker \& Wilms, 2010; Jütting, 2004). ${ }^{1}$ Matching the roll-out of these schemes, studies examining various aspects and effects of CBHI have proliferated, focusing mainly on resource mobilization, insurance uptake, social exclusion, utilization of healthcare, and financial protection. Early reviews of this body of work are provided by Jakab and Krishnan (2001) and Preker, Carrin, Dror, Jakab, Hsiao, and Arhin-Tenkorang (2002). Based on
45 published and unpublished works, Jakab and Krishnan (2001) conclude that there is convincing evidence that community health financing schemes are able to mobilize resources to finance healthcare needs, and that such schemes are effective in terms of reaching low-income groups although the lowest-income groups are often excluded. As opposed to these two narrative reviews, Ekman (2004) provides a systematic review of the literature based on 36 studies conducted during 1980-2002. Echoing previous findings, Ekman (2004) concludes that while such schemes do provide financial protection for low-income groups, the magnitude of the effect is small and the lowest income groups are excluded from enrollment. More recently, based on a systematic review of 46 papers published during 1995-2012, Mebratie, Sparrow, Alemu, and Bedi (2013) examine (among other aspects) the extent of social exclusion and adverse selection in CBHI schemes. They conclude that a majority of papers $(61 \%, 11$ out of 18$)$ find statistically significant evidence of exclusion of the lowest income groups from CBHI schemes. Even when such households become members, they tend to use healthcare services less intensively as compared to higher income groups, potentially due to their inability to afford co-payments and other related costs (such as transportation and forgone income). They also report that $67 \%$ (six out of nine) of the studies find evidence that individuals suffering from chronic health conditions, a proxy for adverse selection, are more likely to join CBHI schemes as compared to those in good health.

In July 2011, the Government of Ethiopia launched a pilot Community-Based Health Insurance (CBHI) scheme, with the aim of enhancing access to health care and reducing the burden of OOP expenditure. The scheme, which caters to rural households and urban informal sector workers, was rolled out in 13 districts located in four main regions (Tigray, Amhara, Oromiya, and SNNPR) of the country. The aim of this paper is to examine and identify factors that drive scheme

\footnotetext{
*We thank two anonymous referees for helpful comments. The authors acknowledge the financial support of the Netherlands Organization for Scientific Research (NWO-WOTRO), grant number W07.45.103.00. Final revision accepted: April 21, 2015.
} 
enrollment. While straightforward this issue is pertinent from a policy perspective as the government plans a nation-wide roll-out of the scheme and hence it is important to examine what factors drive or deter enrollment.

In addition to the policy relevance, this study contributes to the existing empirical literature on CBHI uptake by drawing on a combination of rich survey data on household and health facilities, and mixed qualitative and quantitative methods. First, unlike the bulk of the literature which relies on examining the effect of current traits (such as individual health conditions) on current enrollment and relies on a single post-intervention cross-section of data, we are able to draw on two household surveys canvassed before and after the launch of the CBHI scheme to examine enrollment in 2012 as a function of individual, household, and community traits in 2011. ${ }^{2}$ This enables us to provide estimates that are less likely to be influenced by the endogenous nature of some of the explanatory variables. For instance, post-intervention health status may be endogenous to CBHI enrollment. Second, the paper draws on both survey data and qualitative information gathered through a series of key informant interviews (KII) and focus group discussions (FGD) to identify factors that drive or deter enrollment. Finally, we are able to combine data from a health facility survey conducted prior to the launch of the CBHI scheme with the household survey data to examine the role played by the quality of health care in determining enrollment. While some studies (Chankova, Sulzbach, \& Diop, 2008; Nketiah-Amponsah, 2009; Shimeles, 2010) do control for access to health care by including variables such as distance to the nearest health facility we are able to extend this by directly examining the role of health care quality (such as educational level of health professionals and the availability of medical equipment). ${ }^{3}$

The article unfolds by providing in the next section a description of the key design features of the pilot scheme. Section three describes the data, section four discusses the research methods, section five contains empirical results and the final section concludes.

\section{KEY FEATURES OF THE ETHIOPIAN CBHI SCHEME}

In June 2011 the Ethiopian CBHI scheme was rolled out in 13 pilot districts in four main regions (Tigray, Amhara, Oromiya, and $S N N P R$ ) of the country. ${ }^{4}$ The pilot districts were selected by regional administrative bodies based on directives provided by the Federal Ministry of Health (FMoH). While the chosen districts were expected to fulfill five selection criteria, in practice, selection was based on two conditions. Namely, the district should have undertaken health care financing reforms designed to increase cost recovery and retention of locally raised revenues and that health centers in these districts should be geographically accessible (located close to a main road). ${ }^{5}$

The scheme was introduced by Ethiopia's Federal Ministry of Health $(\mathrm{FMoH})$ in collaboration with USAID, Abt Associates Inc. (2013) and CARE Ethiopia, and is part of the government's broader health care financing reform strategy which aims to improve quality and coverage of health services by identifying alternative healthcare resources (USAID, 2011). Feasibility studies, scheme design, and scheme promotion were outsourced to Abt Associates and CARE Ethiopia. The basic design of the scheme in terms of benefit packages, registration fees, premium payments, and co-payments were determined on the basis of feasibility studies and in collaboration with regional governments and are the same within each of the pilot regions but differ slightly across regions. Scheme implementation and monitoring is conducted by Abt Associates in collaboration with relevant government authorities at the central, regional, district, and village levels.

While the scheme has been introduced by the government, it is "community based" in the sense that the community determines whether or not to join the scheme and is subsequently involved in scheme management and supervision. ${ }^{6}$ In particular, after being exposed to a range of awareness creation activities a general assembly at the village (kebele) level decided whether or not to join the scheme (a simple majority had to support the decision) and then households decide individually whether to enroll in the scheme. ${ }^{7}$ In order to reduce the possibility of adverse selection the unit of membership is the household rather than the individual.

Based on feasibility studies conducted by Abt associates, regional health administration officials determined the premiums to be charged. Household-level monthly premiums for core household members range between Ethiopian Birr (ETB) 10.50 in SNNPR to ETB 15 in Oromiya (see Table 1). ${ }^{8}$ For each non-core household member the monthly premium lies between ETB 2.10 and ETB 3.00. Premiums in the Amhara region are set at ETB 3.00 per individual per month. The premiums amount to about $2-3 \%$ of household monthly income. Based on a comparison with schemes in other African countries, the premium to household income ratio for the Ethiopian scheme tends to be at the lower end of the cost spectrum. ${ }^{9}$ To enhance affordability the central government subsidizes a quarter of the premium and district and regional governments are expected to cover the costs of providing a fee waiver to the poorest $10 \%$ of the population or so called "indigent groups". 10

Premium collection intervals differ across pilot districts and are sensitive to local conditions. While local-level officials and community representatives are able to adjust the interval of premium collection they cannot change the premium. In order to enable community engagement every village is expected to select three delegates/CBHI members who will be part of the village CBHI administrative bodies and participate in the general assembly organized at district level. ${ }^{11}$ According to information obtained from key informant interviews and focus group discussions, village-level government officials and the community at large are involved in identifying the poorest households and implementing the fee waiver arrangement.

The scheme covers both outpatient and inpatient health care services in public facilities. Transportation costs to access health facilities are not covered. Utilization of care from private providers is usually not permitted unless a particular service or drug is unavailable at a public facility. Treatment outside the country is not covered. Scheme participants are expected to access health providers who have signed a contractual agreement with district-level CBHI administrators. The selection of the facilities takes into account a number of factors such as quality of the care (in terms of human resource and equipment), geographical proximity between the providers, and the location of the target households, implementation of the healthcare financing reform, and service charges. There is no upfront payment at the time of service utilization if treatment is obtained from those facilities which have contractual agreements with the scheme. In Tigray, Amhara, and Oromiya regions, $\mathrm{CBHI}$ members are allowed to use care from public facilities that do not have formal contractual agreements with the scheme and then claim reimbursement. There is no reimbursement for service utilization outside CBHI-linked facilities in SNNPR. 
Table 1. CBHI in Ethiopia-premiums, payment intervals, and enrollment

\begin{tabular}{|c|c|c|c|c|c|}
\hline \multirow[t]{2}{*}{ Region } & \multirow[t]{2}{*}{ Unit of contribution } & \multicolumn{2}{|c|}{ Premium per month } & \multirow[t]{2}{*}{ Payment interval } & \multirow{2}{*}{$\begin{array}{l}\text { CBHI uptake in } \\
\text { April } 2012(\%)\end{array}$} \\
\hline & & Core household members & Per extended family member & & \\
\hline Tigray & Household & ETB 11.00 & ETB 2.50 & Annual & 34 \\
\hline Amhara & Individual & ЕТВ 3.00 & ETB 3.00 & Biannual & 49 \\
\hline Oromiya & Household & ETB 15.00 & ETB 3.00 & $\begin{array}{l}\text { Gimbichu district_-annual } \\
\text { Kuyu, Deder, and L. Kossa } \\
\text { districts_-annual or biannual }\end{array}$ & 44 \\
\hline SNNPR & Household & ETB 10.50 & ETB 2.10 & $\begin{array}{l}\text { Yirgalem and D. Woyde-quarterly } \\
\text { Damboya-three times a year }\end{array}$ & 35 \\
\hline Total & & & & & 41 \\
\hline
\end{tabular}

Notes: In addition to the premiums there is a one-time registration fee of ETB 5.00 per household.

Source: Abt Associates and key informant interviews at the federal, district, and regional levels. CBHI uptake rates are the authors' calculations based on the 2012 round of the household survey.

Medical treatments which have largely cosmetic value (for example, artificial teeth and plastic surgery) are excluded. There are no copayments as long as members follow the scheme's referral procedure. When they seek care, scheme members are first expected to visit a health center and can subsequently access higher level care at district or regional hospitals as long as they have referral letters from the health center. Members who visit hospitals without referral letters need to cover $50 \%$ of their costs. Access to tertiary-level care differs across regions. In Amhara and Tigray, CBHI enrollees may visit any public hospital within the region but not outside the region. In SNNPR, care is covered only in the nearest public hospital while in Oromiya coverage includes hospitals located outside the region.

According to our survey data, scheme uptake was $41 \%$ in April 2012 (see Table 1) and according to Abt Associates uptake reached 45.5\% in December 2012 (see Table 2). As compared to the experience of several other African countries the speed of uptake is remarkable. For instance, uptake in Mali was between $3.3 \%$ and $11.4 \%$ after four years (Diop, Sulzbach, \& Chankova, 2006), $4.8 \%$ after two years in Senegal (Smith \& Sulzbach, 2008), 35\% in Rwanda after seven years and $85 \%$ after nine years (Shimeles, 2010).

\section{DATA}

This paper draws on three different types of data-two rounds of a longitudinal household survey, a health facility survey, and qualitative information from key informant interviews and focus group discussions.

Prior to the launch of the CBHI scheme in July 2011, a baseline household survey was conducted between March and April 2011 and a follow-up survey was undertaken between March and April 2012. The household surveys cover 12 of the $13 \mathrm{CBHI}$ pilot districts and four non-intervention districts located in four regions (Tigray, Amhara, Oromoya, and
SNNPR). ${ }^{12}$ From each of the sixteen sampled districts, six villages (Kebeles) were randomly chosen and within each village 17 households were randomly chosen to yield a total of 1,632 households. This paper is based on the surveys conducted in the CBHI pilot districts which include a total of 1,224 households in 2011, of which 1,203 were interviewed again in 2012. ${ }^{13}$

In addition to an extensive module on household and individual health conditions, the surveys contain information on a variety of individual and household socio-economic attributes (consumption expenditure, assets, household demographics, employment), access to formal and informal sources of credit, and involvement in social networks. The health module includes questions regarding self-rated health status and outpatient and inpatient health care utilization for each household member. The recall period for outpatient health care is two months preceding the survey while it is 12 months in the case of inpatient health care. Medical health expenditure including transport costs, consultation and diagnosis costs, drug costs, and other health care-related expenses for each episode of health care consumption are recorded. The second round of the survey enquired whether households had enrolled in the CBHI, and their reasons for doing so.

While the household surveys contain information on access to health facilities (travel time to reach the nearest health facilities), in order to assess and potentially control for the quality of health care services in determining enrollment, we combine the surveys with information gathered from 48 health care centers (three randomly selected health centers from each of the 16 districts). We focused on health centers as these are usually the main source of curative health care in rural Ethiopia. The health facility survey was canvassed between April and May 2011, that is, before the introduction of the CBHI scheme. The health facility survey contains information on the educational qualifications and work experience of the head of the facility, availability of medical equipment, and the head's (self-) assessment of the quality of care provided by the facil-

Table 2. CBHI uptake and fee waiver beneficiaries up to December 31, 2012

\begin{tabular}{|c|c|c|c|c|c|c|c|}
\hline \multirow[t]{3}{*}{ Region } & \multirow[t]{3}{*}{ No of eligible $\mathrm{HHs}$} & \multicolumn{6}{|c|}{ Registered HHs } \\
\hline & & \multicolumn{2}{|c|}{ Paying } & \multicolumn{2}{|c|}{ Non-paying } & \multicolumn{2}{|c|}{ Total } \\
\hline & & $\%$ & $N$ & $\%$ & $N$ & $\%$ & $N$ \\
\hline Amhara & 86,628 & 42.0 & 36,412 & 16.0 & 13,865 & 58.0 & 50,277 \\
\hline Oromiya & 106,674 & 29.3 & 31,301 & 2.6 & 2,750 & 31.9 & 34,051 \\
\hline SNNPR & 32,113 & 53.6 & 17,228 & 4.2 & 1,342 & 57.8 & 18,570 \\
\hline
\end{tabular}

Source: Abt Associates, Addis Ababa, 2013. 
ity. In addition, the survey obtained information from five randomly chosen patients who were exiting from the health center, on the time taken to obtain a patient registration card and time taken between obtaining the registration card and consulting with a health care professional. Based on information provided by the district health offices, households from the 96 sampled villages were matched to the 48 health centers on the basis of household proximity to the health centers. ${ }^{14}$

In order to understand the overall vision of the scheme and to gain a clearer understanding of design, operation, and implementation issues at different levels of government, between December 2012 and January 2013, 15 key informant interviews were conducted. These interviews include $\mathrm{FMoH}$, Abt Associates, Care Ethiopia, four regional-level CBHI coordinators, four district-level CBHI officials and four village-level $\mathrm{CBHI}$ managers from each of the pilot region. Eight focus group discussions, two in each of four villages randomly selected per region, were conducted with groups of seven to twelve individuals. Each FGD had at least three and at most six female participants. One of the FGDs was conducted with scheme members and focused on their motivation for joining the scheme and their views on scheme operation while the other was conducted with non-members and focused on why they had chosen not to join the scheme.

\section{ESTIMATING THE DETERMINANTS OF CBHI ENROLLMENT}

We draw on the theoretical literature as well as the developing country literature on coping with health shocks and demand for insurance (Chetty \& Looney, 2006; Dercon, 2002; Donfouet \& Mahieu, 2012; Mladovsky \& Mossialos, 2008; Schneider, 2004) to develop an appropriate empirical specification to model the probability that a household enrolls in the CBHI scheme. In particular, standard consumer theory emphasizes the role of income and prices in determining insurance uptake. Expected utility theories model the demand for health insurance as a function of risk aversion and a desire to reduce the financial consequences associated with ill-health. State-dependent approaches argue that insurance uptake depends on an individual or household's current health and socio-economic status and the expected pay-off or benefits from insurance which in turn may be treated as a function of insurance coverage and the availability quality of medical care. Prospect theory applied to the insurance context argues that individual decision-making is based on an assessment of premium costs versus health risks and the associated gain or loss prospects. In the developing country context the role of social networks (Mladovsky \& Mossialos, 2008), liquidity constraints (Dercon, 2002), the importance of information, awareness, and knowledge of insurance (Schneider, 2004) and the availability and quality of health care may be expected to play a role in determining the demand for insurance. It is not straightforward to develop empirical counterparts for all the theoretical constructs and there is overlap in the concepts emphasized by different theories. Most prominently, socio-economic status, health status (anticipated need for care), and the expected pay-off from insurance (extent of coverage, availability, and quality of health care), appear to be relatively common elements. Keeping in mind the common variables emphasized in the various theories, the context under study as well as data constraints we focus on the role of household socio-economic status and demographic structure, health status, and past use of health care services, access to social networks and credit, and access to and quality of health care, in determining enrollment. Thus, the enrollment status of house- hold $h$ in time period $t$ (2012) is expressed as a function of various sets of variables in period $t-l$ (2011) and written as,

$$
\begin{aligned}
\mathrm{P}\left(\mathrm{CBHI}_{h t}=1\right)= & F\left(\alpha^{\prime} \mathrm{SES}_{h t-1}+\theta^{\prime} \mathrm{DE}_{h t-1}+\beta^{\prime} \mathrm{HS}_{h t-1}\right. \\
& \left.+\gamma^{\prime} \mathrm{FISC}_{h t-1}+\delta^{\prime} \mathrm{SSA}_{h t-1}+\eta^{\prime} \mathrm{SSQ}_{h t-1}+\varepsilon_{h t}\right)
\end{aligned}
$$

where $\mathrm{CBHI}$ is a binary variable with a value of one if a household is enrolled in the scheme and zero otherwise. Socio-economic status (SES) is a set of variables that includes the educational status of the head of the household, whether a household participates in a social security program called the productive safety net program (PSNP) which targets chronically food-insecure households and the consumption quintile in which a household falls. ${ }^{15}{ }^{16}$ Households in higher consumption quintiles and with more educated household heads are more likely to be able to afford the insurance premium and may also be better informed. DE is a set of variables that captures the demographic profile of households and includes the gender of the household head, household size, proportion of male and female household members in different age groups, and religion of the household head. To account for anticipated health care needs, in determining enrollment status we include a set of variables (HS) indicating past illness events, incidence of chronic disease, use of outpatient and inpatient care, outpatient and inpatient health care expenditure, and household self-reported health status (good, fair/poor). FISC includes variables that control for access to formal and informal sources of credit and the strength of a household's social network. These include variables such as whether a household has savings in a bank account, outstanding loans, is a member of a credit and savings association, and member of an Iqqub. ${ }^{17}$ The strength of a household's social network is proxied, among other variables, by membership in a Wonfel or a Debo, membership in church/mosque-based religious groups, and whether any household member has ever held or holds an official government position. ${ }^{18}$ A priori the effect of these variables on insurance uptake is not clear. On the one hand households with access to credit and embedded in larger social networks may be better able to cope with ill-health even in the absence of health insurance and may find such schemes less attractive. On the other hand households with easier access to credit may find it easier to pay insurance premiums while those embedded in existing social networks may be more receptive to the idea of insurance.

We include two sets of supply side characteristics. First, access to health care facilities (SSA) includes travel time to health centers and hospitals. Second, an array of variables that capture the quality of health care on offer (SSQ) include information on the education and training of the head of the facility, availability of medical equipment, waiting time to obtain a patient card and to see a medical care provider, and the perception of the quality of care provided by the facility as reported by its head. ${ }^{19} \mathrm{We}$ expect that easier access to health care and the availability of higher quality of care is likely to increase the expected benefits of insurance and thereby increase the probability of enrolling. In addition, we also include a set of regional controls and control for community-level access to infrastructure (roads, access to water, and electricity).

A description of the variables and summary statistics are provided in Appendix A and Table 3, respectively.

\section{RESULTS}

We estimate Eqn. (1) using a logit model. To explore the sensitivity of the estimates to different ways of measuring health 
Table 3. Descriptive statistics by insurance status, 2011

\begin{tabular}{|c|c|c|c|c|c|c|c|}
\hline \multirow[t]{2}{*}{ Variable } & \multicolumn{2}{|c|}{ Enrolled } & \multicolumn{2}{|c|}{ Non-Enrolled } & \multirow[t]{2}{*}{ Mean differences $p$-value } & \multicolumn{2}{|c|}{ Total } \\
\hline & Mean & SD & Mean & SD & & Mean & $\mathrm{SD}$ \\
\hline \multicolumn{8}{|l|}{ Socioeconomic status } \\
\hline Poorest consumption quintile & 0.23 & 0.42 & 0.18 & 0.39 & 0.0462 & 0.20 & 0.40 \\
\hline 2nd consumption quintile & 0.20 & 0.40 & 0.20 & 0.40 & 0.9255 & 0.20 & 0.40 \\
\hline 3rd consumption quintile & 0.19 & 0.39 & 0.21 & 0.41 & 0.3832 & 0.20 & 0.40 \\
\hline 4th consumption quintile & 0.18 & 0.38 & 0.21 & 0.41 & 0.1301 & 0.20 & 0.40 \\
\hline Richest consumption quintile & 0.20 & 0.40 & 0.20 & 0.40 & 0.7655 & 0.20 & 0.40 \\
\hline HH head education-No education at all & 0.42 & 0.49 & 0.48 & 0.50 & 0.0387 & 0.46 & 0.50 \\
\hline HH head education-Informal & 0.16 & 0.37 & 0.11 & 0.32 & 0.0214 & 0.13 & 0.34 \\
\hline HH head education-Primary or above & 0.42 & 0.49 & 0.40 & 0.49 & 0.6313 & 0.41 & 0.49 \\
\hline Participates in PSNP & 0.28 & 0.45 & 0.17 & 0.38 & 0.0000 & 0.21 & 0.41 \\
\hline \multicolumn{8}{|l|}{ Demographic traits } \\
\hline Male-headed HH & 0.90 & 0.31 & 0.84 & 0.36 & 0.0108 & 0.87 & 0.34 \\
\hline Age of $\mathrm{HH}$ head & 46.91 & 12.68 & 46.79 & 14.75 & 0.8860 & 46.84 & 13.96 \\
\hline Household size & 6.25 & 2.21 & 5.61 & 2.26 & 0.0000 & 5.87 & 2.26 \\
\hline Prop. of children aged under 6 & 0.13 & 0.14 & 0.15 & 0.16 & 0.0669 & 0.14 & 0.15 \\
\hline Prop. of male aged 6 to 15 & 0.17 & 0.15 & 0.15 & 0.15 & 0.0766 & 0.16 & 0.15 \\
\hline Prop. of female aged 6 to 15 & 0.16 & 0.14 & 0.14 & 0.15 & 0.0108 & 0.15 & 0.15 \\
\hline Prop. of male aged 16 to 64 & 0.26 & 0.15 & 0.25 & 0.17 & 0.4008 & 0.25 & 0.16 \\
\hline Prop. of female aged 16 to 64 & 0.25 & 0.14 & 0.26 & 0.16 & 0.7691 & 0.25 & 0.15 \\
\hline Prop. of elderly aged above 64 & 0.03 & 0.11 & 0.06 & 0.18 & 0.0029 & 0.05 & 0.15 \\
\hline HH head religion-Orthodox Christian & 0.62 & 0.49 & 0.59 & 0.49 & 0.3421 & 0.61 & 0.49 \\
\hline $\mathrm{HH}$ head religion-Protestant & 0.18 & 0.38 & 0.21 & 0.41 & 0.1920 & 0.20 & 0.40 \\
\hline $\mathrm{HH}$ head religion-Muslim & 0.19 & 0.39 & 0.17 & 0.38 & 0.4022 & 0.18 & 0.38 \\
\hline HH head religion - Other religion or no religion & 0.01 & 0.10 & 0.03 & 0.16 & 0.0535 & 0.02 & 0.14 \\
\hline \multicolumn{8}{|l|}{ Health status and health care use } \\
\hline Prop. of household members with good SAH & 0.81 & 0.32 & 0.74 & 0.38 & 0.0015 & 0.77 & 0.35 \\
\hline Prop. of household members with poor SAH & 0.19 & 0.31 & 0.26 & 0.38 & 0.0013 & 0.23 & 0.35 \\
\hline Past illness event & 8.75 & 16.06 & 9.13 & 16.61 & 0.6881 & 8.98 & 16.39 \\
\hline Chronic illness & 0.24 & 0.65 & 0.35 & 0.31 & 0.0216 & 0.31 & 0.82 \\
\hline Outpatient care use & 0.39 & 0.49 & 0.38 & 0.48 & 0.6288 & 0.38 & 0.49 \\
\hline Inpatient care use & 0.03 & 0.17 & 0.03 & 0.18 & 0.6913 & 0.03 & 0.17 \\
\hline Outpatient healthcare expenditure & 80.21 & 307.81 & 42.33 & 129.87 & 0.0031 & 57.47 & 219.71 \\
\hline Inpatient healthcare expenditure & 44.40 & 415.49 & 40.81 & 451.0 & 0.8883 & 8.98 & 16.39 \\
\hline Trust in modern care-Not agree & 0.10 & 0.30 & 0.11 & 0.32 & 0.3564 & 0.11 & 0.31 \\
\hline Trust in modern care-Agree & 0.90 & 0.30 & 0.89 & 0.32 & 0.3564 & 0.89 & 0.31 \\
\hline \multicolumn{8}{|l|}{ Formal and informal access to credit and networks } \\
\hline Member of Iqqub & 0.08 & 0.27 & 0.06 & 0.24 & 0.1140 & 0.07 & 0.25 \\
\hline Member of credit and saving association & 0.17 & 0.38 & 0.09 & 0.29 & 0.0000 & 0.12 & 0.33 \\
\hline Member of religious group & 0.59 & 0.49 & 0.60 & 0.49 & 0.8083 & 0.59 & 0.49 \\
\hline Participate in Wonfel or Debo & 0.46 & 0.50 & 0.43 & 0.50 & 0.3777 & 0.44 & 0.50 \\
\hline Savings in bank account & 0.16 & 0.37 & 0.12 & 0.33 & 0.0311 & 0.14 & 0.35 \\
\hline Outstanding loan & 0.38 & 0.49 & 0.28 & 0.45 & 0.0006 & 0.32 & 0.47 \\
\hline Someone to rely on & 0.40 & 0.49 & 0.37 & 0.48 & 0.2846 & 0.38 & 0.49 \\
\hline Official position held & 0.29 & 0.46 & 0.19 & 0.39 & 0.0000 & 0.23 & 0.42 \\
\hline \multicolumn{8}{|l|}{ Supply side characteristics } \\
\hline Travel time to health center & 70.00 & 46.94 & 64.07 & 43.37 & 0.0235 & 66.44 & 44.90 \\
\hline Travel time to public hospital & 113.58 & 65.83 & 114.44 & 75.51 & 0.8373 & 114.10 & 71.77 \\
\hline Completed first degree $(12+3)$ & 0.45 & 0.50 & 0.46 & 0.50 & 0.6293 & 0.46 & 0.50 \\
\hline Received on the job training & 0.81 & 0.39 & 0.83 & 0.38 & 0.4754 & 0.82 & 0.38 \\
\hline Availability of blood-testing equipment & 0.92 & 0.26 & 0.77 & 0.42 & 0.0000 & 0.83 & 0.37 \\
\hline Availability of urine-testing equipment & 0.94 & 0.24 & 0.88 & 0.33 & 0.0005 & 0.90 & 0.30 \\
\hline Waiting time to get patient card & 10.56 & 10.06 & 14.60 & 12.59 & 0.0000 & 12.99 & 11.81 \\
\hline Waiting time to see a medical professional & 28.33 & 23.97 & 38.48 & 29.42 & 0.0000 & 34.43 & 27.81 \\
\hline Perceived quality of care & 0.65 & 0.48 & 0.40 & 0.49 & 0.0000 & 0.50 & 0.50 \\
\hline \multicolumn{8}{|l|}{ Community characteristics } \\
\hline Region-Tigray & 0.21 & 0.41 & 0.28 & 0.45 & 0.0042 & 0.25 & 0.43 \\
\hline Region-Amhara & 0.30 & 0.46 & 0.21 & 0.41 & 0.0005 & 0.25 & 0.43 \\
\hline Region-Oromiya & 0.27 & 0.45 & 0.24 & 0.42 & 0.1476 & 0.25 & 0.43 \\
\hline Region-SNNPR & 0.22 & 0.41 & 0.27 & 0.44 & 0.0399 & 0.25 & 0.43 \\
\hline Observations & \multicolumn{2}{|c|}{489} & \multicolumn{2}{|c|}{735} & & \multicolumn{2}{|c|}{1224} \\
\hline
\end{tabular}


status we present four different sets of estimates. All the models include information on self-assessed health status. In addition, model 1 includes incidence of illnesses in the last two months and an indicator for chronic disease. Model 2 includes variables indicating use of health care. Model 3 incorporates the incidence of illnesses and use of health care while model 4 includes expenditure on health care. Marginal effect estimates, with standard errors clustered at the level of the primary sampling unit (the village), are provided in Table 4. Table 5 contains information on the main reasons for purchasing insurance.

Unlike the bulk of the existing papers on enrollment in $\mathrm{CBHI}$, which find that the lowest-income groups are often excluded from the scheme, uptake of the Ethiopian CBHI program reveals the opposite, with the poorest quintile providing the largest share of CBHI beneficiaries (Table 3). The logit estimates suggest that this inclusion of the poorest is partly driven by participation in the productive safety net program (PSNP), which targets chronically food-insecure households and is associated with a 31 to 33 percentage point increase in CBHI enrollment. ${ }^{20}$ The educational status of the household head and the consumption quintile in which a household falls have no statistically significant bearing on enrollment. The relative pro-poor character of the CBHI uptake may in part be attributed to the relatively low premium and potentially the fee-waiver targeted to indigent households. However, estimates dropping households that do not pay a premium are not substantially different (see Appendix B) from the estimates reported in Table 4. ${ }^{21}$

The qualitative information gathered through the key informant interviews and via observations in the field suggests two reasons for the remarkably large effect of PSNP participation. First, government officials have been taking measures to integrate different development interventions such as agricultural extension, education, and health programs. Households covered by the PSNP are provided information on the health insurance scheme and encouraged to enroll. This is illustrated by a statement made by a key informant in the Tigray region,

Continuous education on health issues including about the recently introduced community-based health insurance scheme is provided to those people who are covered under PSNP. Moreover, during the distribution of PSNP payments, the participants are asked if they would like to register for $\mathrm{CBHI}$ and those who volunteer to pay immediately and join

[Interviewed on December 07, 2012]

Second, while the pro-poor tilt of the scheme is a positive aspect it is possible that the enrollment of PSNP beneficiaries may not be entirely voluntary. Village-level CBHI officials may exert pressure and force households to enroll. Our data show that about 10\% (50 out of 489) of insured households indicate that their main reason for joining the scheme is pressure from CBHI officials (Table 5). In relation to this, an uninsured FGD participant in the Oromiya region said,

A kebele (village) official reduced my monthly income from PSNP and informed me that the reduced money was for CBHI membership contribution. I said I did not want to enroll in the scheme and asked him to give me my full PSNP benefit. However, he did not pay me. So, I accused him to a higher kebele official and I got my money back

[Discussed on December 23, 2013]

Notwithstanding this remark, estimates dropping households who receive a fee-waiver and those who reported that they were pressured to join the scheme are not very different from the estimates reported in Table 4 (see Appendix C). The PSNP effect declines marginally but remains large and statistically significant.

The gender and age distribution of household members may affect CBHI uptake. For instance, households with more chil- dren, a greater proportion of elderly household members, or adult females in the reproductive age group may be more likely to demand health insurance and health care. Some evidence of this is available in Table 4. However, apart from household size, which is associated with a two percentage point increase in the probability of enrollment there is no statistically significant relationship between household composition and scheme enrollment. In three of the four regions (Tigray, Oromiya, and SNNPR) the insurance contribution is fixed per household and hence the scheme may be especially attractive for households with a large family size. Orthodox Christians are about $13-14$ percentage points more likely to join the scheme as compared to other religions. The reasons for this are not entirely clear.

There is no evidence that poor self-assessed health status has a bearing on enrollment. Similarly, illnesses, incidence of chronic diseases, duration of hospitalization, and utilization of care (outpatient and inpatient) are not positively linked to CBHI uptake. In fact, there is a negative link between enrollment and chronic disease. While pre-existing medical conditions and utilization may not induce uptake it does seem that recent episodes of health care spending on outpatient care prompt enrollment - a half a standard deviation increase, about 100 Birr, in outpatient expenditure is associated with a 2.4 percentage point increase in enrollment. Nevertheless, only about $8 \%$ of insured households reported that they joined the scheme because of frequent illnesses in their households (see Table 5). The existing papers, of which six out of nine find evidence of adverse selection, tend to use the incidence of illness as their selection measure. If we were to use a similar measure then we would conclude that adverse selection is unlikely to be major concern in the current scheme. While it is hard to make a definitive claim, perhaps a key reason for the lack of selection effects is that, in order to discourage enrollment on the basis of pre-existing medical conditions, enrollment is permitted only at the household and not at the individual level. This is similar to the design of several schemes which use group enrollment as a mechanism to tackle adverse selection in scheme uptake (De Allegri et al., 2006; Palmer, 2014).

Access to formal and informal sources of credit and membership in social networks may have a positive or a negative effect on demand for health insurance. On the one hand, belonging to a network may reduce the incentive to participate in the CBHI scheme while at the same time such networks may be sources of finance to purchase insurance and may also help enhance understanding of health insurance. The key informant interviews and the focus group discussions revealed that various social networks such as Iddir (funeral association), Iqqub, and religious groups were used to raise understanding of CBHI and to persuade households to join the scheme. However, except for the variable which indicates that a household member holds or held an official government position, none of the credit or network-related variables have a bearing on enrollment. Holding or ever having held an administrative or community leadership position enhances CBHI enrollment by about 10 percentage points. This is perhaps not surprising. The qualitative data collection efforts show that in all regions, kebele officials and community leaders were provided information and understanding of the scheme and were expected to inform their constituencies and help generate interest in the scheme.

Turning to supply side factors, contrary to expectations, there is a positive association between travel time to health centers and CBHI membership. A one standard deviation increase (about $45 \mathrm{~min}$ ) in travel time increases enrollment by 3.6 percentage points. Travel time to public hospitals does not have a bearing on CBHI uptake. While unexpected the 
Table 4. Probability of enrollment-marginal effects (std. error)

\begin{tabular}{|c|c|c|c|c|}
\hline Variables & Model 1 & Model 2 & Model 3 & Model 4 \\
\hline \multicolumn{5}{|l|}{ Socioeconomic status } \\
\hline 2nd consumption quintile (ref: poorest consumption quintile) & $\begin{array}{c}0.000186 \\
(0.0503)\end{array}$ & $\begin{array}{c}0.00552 \\
(0.0513)\end{array}$ & $\begin{array}{c}0.00243 \\
(0.0509)\end{array}$ & $\begin{array}{l}0.00627 \\
(0.0513)\end{array}$ \\
\hline 3rd consumption quintile & $\begin{array}{c}0.0192 \\
(0.0507)\end{array}$ & $\begin{array}{c}0.0275 \\
(0.0517)\end{array}$ & $\begin{array}{c}0.0214 \\
(0.0513)\end{array}$ & $\begin{array}{c}0.0282 \\
(0.0518)\end{array}$ \\
\hline 4th consumption quintile & $\begin{array}{c}0.0332 \\
(0.0534)\end{array}$ & $\begin{array}{c}0.0335 \\
(0.0528)\end{array}$ & $\begin{array}{c}0.0329 \\
(0.0536)\end{array}$ & $\begin{array}{c}0.0317 \\
(0.0527)\end{array}$ \\
\hline Richest consumption quintile & $\begin{array}{c}0.0838 \\
(0.0685)\end{array}$ & $\begin{array}{c}0.0871 \\
(0.0700)\end{array}$ & $\begin{array}{c}0.0842 \\
(0.0695)\end{array}$ & $\begin{array}{c}0.0864 \\
(0.0689)\end{array}$ \\
\hline HH head education-Informal (ref: no education at all) & $\begin{array}{c}0.0135 \\
(0.0517)\end{array}$ & $\begin{array}{c}0.0119 \\
(0.0513)\end{array}$ & $\begin{array}{c}0.0119 \\
(0.0518)\end{array}$ & $\begin{array}{l}0.00736 \\
(0.0510)\end{array}$ \\
\hline HH head education-Primary or above & $\begin{array}{c}0.0369 \\
(0.0454)\end{array}$ & $\begin{array}{c}0.0385 \\
(0.0454)\end{array}$ & $\begin{array}{c}0.0361 \\
(0.0454)\end{array}$ & $\begin{array}{c}0.0329 \\
(0.0456)\end{array}$ \\
\hline Participated in PSNP & $\begin{array}{l}0.316^{* * *} \\
(0.0639)\end{array}$ & $\begin{array}{l}0.320^{* * *} \\
(0.0644)\end{array}$ & $\begin{array}{l}0.316^{* * *} \\
(0.0640)\end{array}$ & $\begin{array}{l}0.327^{* * *} \\
(0.0637)\end{array}$ \\
\hline \multicolumn{5}{|l|}{ Demographic traits } \\
\hline Male-headed HH & $\begin{array}{c}0.0312 \\
(0.0520)\end{array}$ & $\begin{array}{c}0.0337 \\
(0.0503)\end{array}$ & $\begin{array}{c}0.0312 \\
(0.0516)\end{array}$ & $\begin{array}{c}0.0345 \\
(0.0504)\end{array}$ \\
\hline Age of HH head & $\begin{array}{l}0.000915 \\
(0.00178)\end{array}$ & $\begin{array}{l}0.000898 \\
(0.00178)\end{array}$ & $\begin{array}{l}0.000897 \\
(0.00178)\end{array}$ & $\begin{array}{l}0.000999 \\
(0.00179)\end{array}$ \\
\hline Household size & $\begin{array}{c}0.0212^{* *} \\
(0.00979)\end{array}$ & $\begin{array}{c}0.0208^{* *} \\
(0.00985)\end{array}$ & $\begin{array}{c}0.0210^{* *} \\
(0.00991)\end{array}$ & $\begin{array}{c}0.0193^{*} \\
(0.00998)\end{array}$ \\
\hline Prop. of children aged under 6 (ref: Prop. of male aged 16-64) & $\begin{array}{c}-0.0925 \\
(0.177)\end{array}$ & $\begin{array}{l}-0.102 \\
(0.177)\end{array}$ & $\begin{array}{c}-0.0968 \\
(0.176)\end{array}$ & $\begin{array}{c}-0.0673 \\
(0.180)\end{array}$ \\
\hline Prop. of male aged $6-15$ & $\begin{array}{c}0.000736 \\
(0.165)\end{array}$ & $\begin{array}{c}0.000462 \\
(0.165)\end{array}$ & $\begin{array}{c}-0.00118 \\
(0.165)\end{array}$ & $\begin{array}{l}0.0220 \\
(0.165)\end{array}$ \\
\hline Prop. of female aged $6-15$ & $\begin{array}{c}0.124 \\
(0.167)\end{array}$ & $\begin{array}{c}0.121 \\
(0.163)\end{array}$ & $\begin{array}{c}0.116 \\
(0.166)\end{array}$ & $\begin{array}{c}0.137 \\
(0.165)\end{array}$ \\
\hline Prop. of female aged $16-64$ & $\begin{array}{l}0.0782 \\
(0.201)\end{array}$ & $\begin{array}{l}0.0724 \\
(0.201)\end{array}$ & $\begin{array}{l}0.0751 \\
(0.200)\end{array}$ & $\begin{array}{l}0.0926 \\
(0.201)\end{array}$ \\
\hline Prop. of elderly aged above 64 & $\begin{array}{l}-0.178 \\
(0.160)\end{array}$ & $\begin{array}{l}-0.164 \\
(0.158)\end{array}$ & $\begin{array}{l}-0.177 \\
(0.159)\end{array}$ & $\begin{array}{l}-0.155 \\
(0.163)\end{array}$ \\
\hline HH head religion-Orthodox Christian (ref: Muslim) & $\begin{array}{c}0.135^{*} \\
(0.0725)\end{array}$ & $\begin{array}{c}0.132^{*} \\
(0.0721)\end{array}$ & $\begin{array}{c}0.135^{*} \\
(0.0724)\end{array}$ & $\begin{array}{c}0.142^{*} \\
(0.0725)\end{array}$ \\
\hline HH head religion-Protestant & $\begin{array}{c}0.100 \\
(0.102)\end{array}$ & $\begin{array}{l}0.0986 \\
(0.103)\end{array}$ & $\begin{array}{c}0.102 \\
(0.102)\end{array}$ & $\begin{array}{c}0.105 \\
(0.103)\end{array}$ \\
\hline HH head religion-Other religion or no religion & $\begin{array}{c}-0.0580 \\
(0.130)\end{array}$ & $\begin{array}{c}-0.0612 \\
(0.127)\end{array}$ & $\begin{array}{c}-0.0591 \\
(0.128)\end{array}$ & $\begin{array}{c}-0.0384 \\
(0.132)\end{array}$ \\
\hline \multicolumn{5}{|l|}{ Health status and health care use } \\
\hline Prop. of household members with poor SAH (ref: Prop. of household members with good SAH) & $\begin{array}{l}-0.0452 \\
(0.0579)\end{array}$ & $\begin{array}{l}-0.0538 \\
(0.0559)\end{array}$ & $\begin{array}{l}-0.0480 \\
(0.0573)\end{array}$ & $\begin{array}{l}-0.0646 \\
(0.0559)\end{array}$ \\
\hline Past illness event & $\begin{array}{c}0.00141 \\
(0.00105)\end{array}$ & & $\begin{array}{c}0.00127 \\
(0.00119)\end{array}$ & \\
\hline Chronic illness & $\begin{array}{l}-0.0281 \\
(0.0212)\end{array}$ & & $\begin{array}{l}-0.0276 \\
(0.0212)\end{array}$ & \\
\hline Outpatient care use & & $\begin{array}{c}0.0279 \\
(0.0320)\end{array}$ & $\begin{array}{c}0.0186 \\
(0.0369)\end{array}$ & \\
\hline Inpatient care use & & $\begin{array}{l}-0.0535 \\
(0.0865)\end{array}$ & $\begin{array}{l}-0.0587 \\
(0.0850)\end{array}$ & \\
\hline Outpatient healthcare expenditure & & & & $\begin{array}{l}0.000237^{* *} \\
(0.000105)\end{array}$ \\
\hline Inpatient healthcare expenditure & & & & $\begin{array}{l}-1.93 \mathrm{e}-05 \\
(2.47 \mathrm{e}-05)\end{array}$ \\
\hline Trust in modern care-Agree (ref: Not agree) & $\begin{array}{c}0.0930 \\
(0.0583)\end{array}$ & $\begin{array}{c}0.0935 \\
(0.0580)\end{array}$ & $\begin{array}{c}0.0928 \\
(0.0581)\end{array}$ & $\begin{array}{c}0.0922 \\
(0.0587)\end{array}$ \\
\hline \multicolumn{5}{|l|}{ Formal and informal access to credit and social networks } \\
\hline Member of Iqqub & $\begin{array}{c}0.0550 \\
(0.0758)\end{array}$ & $\begin{array}{c}0.0596 \\
(0.0747)\end{array}$ & $\begin{array}{c}0.0549 \\
(0.0755)\end{array}$ & $\begin{array}{c}0.0656 \\
(0.0739)\end{array}$ \\
\hline Member of credit and savings association & $\begin{array}{c}0.0273 \\
(0.0661)\end{array}$ & $\begin{array}{c}0.0244 \\
(0.0661)\end{array}$ & $\begin{array}{c}0.0256 \\
(0.0656)\end{array}$ & $\begin{array}{c}0.0260 \\
(0.0675)\end{array}$ \\
\hline Member of religious group & $\begin{array}{c}0.0252 \\
(0.0377)\end{array}$ & $\begin{array}{c}0.0270 \\
(0.0370)\end{array}$ & $\begin{array}{c}0.0239 \\
(0.0373)\end{array}$ & $\begin{array}{c}0.0256 \\
(0.0369)\end{array}$ \\
\hline
\end{tabular}


Table 4 (continued)

\begin{tabular}{|c|c|c|c|c|}
\hline Variables & Model 1 & Model 2 & Model 3 & Model 4 \\
\hline Participate in Wonfel or Debo & $\begin{array}{c}0.0335 \\
(0.0443)\end{array}$ & $\begin{array}{c}0.0332 \\
(0.0440)\end{array}$ & $\begin{array}{c}0.0313 \\
(0.0446)\end{array}$ & $\begin{array}{c}0.0376 \\
(0.0444)\end{array}$ \\
\hline Savings in bank account & $\begin{array}{c}0.0440 \\
(0.0599)\end{array}$ & $\begin{array}{c}0.0415 \\
(0.0591)\end{array}$ & $\begin{array}{c}0.0446 \\
(0.0587)\end{array}$ & $\begin{array}{c}0.0387 \\
(0.0599)\end{array}$ \\
\hline Outstanding loan & $\begin{array}{c}0.0652 \\
(0.0489)\end{array}$ & $\begin{array}{c}0.0664 \\
(0.0490)\end{array}$ & $\begin{array}{c}0.0640 \\
(0.0492)\end{array}$ & $\begin{array}{c}0.0680 \\
(0.0496)\end{array}$ \\
\hline Someone to rely on & $\begin{array}{l}-0.0238 \\
(0.0291)\end{array}$ & $\begin{array}{l}-0.0282 \\
(0.0293)\end{array}$ & $\begin{array}{l}-0.0244 \\
(0.0293)\end{array}$ & $\begin{array}{l}-0.0278 \\
(0.0293)\end{array}$ \\
\hline Official position held & $\begin{array}{c}0.104^{* *} \\
(0.0430)\end{array}$ & $\begin{array}{c}0.103^{* *} \\
(0.0429)\end{array}$ & $\begin{array}{c}0.104^{* *} \\
(0.0433)\end{array}$ & $\begin{array}{l}0.0974^{* *} \\
(0.0415)\end{array}$ \\
\hline \multicolumn{5}{|l|}{ Supply side characteristics } \\
\hline Travel time to health center & $\begin{array}{l}0.000820^{* *} \\
(0.000383)\end{array}$ & $\begin{array}{l}0.000865^{* *} \\
(0.000387)\end{array}$ & $\begin{array}{l}0.000845^{* *} \\
(0.000386)\end{array}$ & $\begin{array}{l}0.000851^{* *} \\
(0.000391)\end{array}$ \\
\hline Travel time to public hospital & $\begin{array}{c}3.90 \mathrm{e}-05 \\
(0.000335)\end{array}$ & $\begin{array}{c}4.96 \mathrm{e}-05 \\
(0.000336)\end{array}$ & $\begin{array}{c}3.25 \mathrm{e}-05 \\
(0.000336)\end{array}$ & $\begin{array}{c}7.58 \mathrm{e}-05 \\
(0.000337)\end{array}$ \\
\hline Completed first degree $(12+3)$ & $\begin{array}{c}-0.103 \\
(0.0744)\end{array}$ & $\begin{array}{c}-0.105 \\
(0.0737)\end{array}$ & $\begin{array}{c}-0.104 \\
(0.0744)\end{array}$ & $\begin{array}{c}-0.110 \\
(0.0745)\end{array}$ \\
\hline Received on the job training & $\begin{array}{l}-0.0597 \\
(0.0905)\end{array}$ & $\begin{array}{l}-0.0653 \\
(0.0912)\end{array}$ & $\begin{array}{l}-0.0623 \\
(0.0904)\end{array}$ & $\begin{array}{l}-0.0641 \\
(0.0919)\end{array}$ \\
\hline Availability of blood-testing equipment & $\begin{array}{l}0.298^{* * *} \\
(0.0612)\end{array}$ & $\begin{array}{l}0.296^{* * *} \\
(0.0616)\end{array}$ & $\begin{array}{l}0.297^{* * *} \\
(0.0615)\end{array}$ & $\begin{array}{l}0.302^{* * *} \\
(0.0615)\end{array}$ \\
\hline Availability of urine-testing equipment & $\begin{array}{l}-0.119 \\
(0.114)\end{array}$ & $\begin{array}{l}-0.124 \\
(0.115)\end{array}$ & $\begin{array}{l}-0.122 \\
(0.113)\end{array}$ & $\begin{array}{l}-0.114 \\
(0.115)\end{array}$ \\
\hline Waiting time to get patient card & $\begin{array}{l}-0.00127 \\
(0.00457)\end{array}$ & $\begin{array}{l}-0.00146 \\
(0.00454)\end{array}$ & $\begin{array}{l}-0.00124 \\
(0.00456)\end{array}$ & $\begin{array}{l}-0.00159 \\
(0.00454)\end{array}$ \\
\hline Waiting time to see a medical professional & $\begin{array}{c}-0.00507^{* *} \\
(0.00215)\end{array}$ & $\begin{array}{c}-0.00513^{* *} \\
(0.00216)\end{array}$ & $\begin{array}{c}-0.00513^{* *} \\
(0.00216)\end{array}$ & $\begin{array}{c}-0.00498^{* *} \\
(0.00216)\end{array}$ \\
\hline Perceived quality of care & $\begin{array}{l}0.195^{* * *} \\
(0.0611)\end{array}$ & $\begin{array}{l}0.197^{* * *} \\
(0.0607)\end{array}$ & $\begin{array}{l}0.195^{* * *} \\
(0.0614)\end{array}$ & $\begin{array}{l}0.192^{* * *} \\
(0.0613)\end{array}$ \\
\hline \multicolumn{5}{|l|}{ Community characteristics } \\
\hline Region-Tigray (ref: SNNPR) & $\begin{array}{l}0.0300 \\
(0.124)\end{array}$ & $\begin{array}{l}0.0309 \\
(0.123)\end{array}$ & $\begin{array}{l}0.0348 \\
(0.123)\end{array}$ & $\begin{array}{l}0.0284 \\
(0.123)\end{array}$ \\
\hline Region-Amhara & $\begin{array}{l}0.200^{*} \\
(0.117)\end{array}$ & $\begin{array}{l}0.201^{*} \\
(0.116)\end{array}$ & $\begin{array}{l}0.205^{*} \\
(0.116)\end{array}$ & $\begin{array}{l}0.202^{*} \\
(0.117)\end{array}$ \\
\hline Region-Oromiya & $\begin{array}{l}0.212^{*} \\
(0.118)\end{array}$ & $\begin{array}{l}0.215^{*} \\
(0.117)\end{array}$ & $\begin{array}{l}0.216^{*} \\
(0.117)\end{array}$ & $\begin{array}{l}0.220^{*} \\
(0.119)\end{array}$ \\
\hline Observations & 1,203 & 1,205 & 1,203 & 1,205 \\
\hline Pseudo $R$-squared & 0.1805 & 0.1802 & 0.1810 & 0.1842 \\
\hline Log pseudo likelihood & -663.411 & -664.814 & -663.043 & -661.559 \\
\hline
\end{tabular}

Notes: Outcome variable is CBHI enrollment status in 2012 and all explanatory variables are at their baseline (2011) values; clustered standard errors in parentheses; ${ }^{* * *} p<0.01,{ }^{* *} p<0.05,{ }^{*} p<0.1$.

Table 5. Single most important reason for (not) enrolling and intention to alter insurance status

\begin{tabular}{|c|c|c|c|}
\hline Insured households $(N=489)$ & $N(\%)$ & Uninsured households $(N=735)$ & $N(\%)$ \\
\hline Reasons for enrollment (percent of insured households) & & $\begin{array}{l}\text { Reasons for not enrolling in CBHI (percent of uninsured } \\
\text { but eligible households) }\end{array}$ & \\
\hline Illness and/or injury occurs frequently in the household & $39(8.1)$ & Illness and injury does not occur frequently in the household & $31(5.2)$ \\
\hline Pregnant women in the household need health care services & $34(7.0)$ & The registration fee and premiums are not affordable & $203(34.2)$ \\
\hline Child/children in the households need health care services & $37(7.7)$ & Want to wait in order to confirm the benefit & $117(19.7)$ \\
\hline To finance health care expenses & $152(31.5)$ & Lack of awareness about the scheme & $133(22.4)$ \\
\hline The household is exempt from registration fee and premium & $22(4.6)$ & Shortage of money & $32(5.4)$ \\
\hline Premium is low compared to user fee & $120(24.8)$ & Limited availability of health services & $13(2.2)$ \\
\hline Pressure from CBHI officials & $50(10.4)$ & Quality of health care services is low & $17(2.9)$ \\
\hline Other reasons & $29(6.0)$ & Other reasons & $47(7.9)$ \\
\hline $\begin{array}{l}\text { Insured households who plan to renew their CBHI } \\
\text { membership }\end{array}$ & $466(96.1)$ & Uninsured households who plan to enroll in the future & $404(57.1)$ \\
\hline
\end{tabular}

positive link between travel time and enrollment may be driven by the higher costs (transportation and health care related) of obtaining health care for households living in more inaccessible areas which may provide a stronger incentive to enroll. There is a clear and discernible link between the quality of care on offer and CBHI uptake. For instance, availability of blood-testing equipment in the closest health facility increases the probability of CBHI enrollment by 30 percentage points. Average waiting time to see a health care professional, a measure of quality in its own right and a proxy for facility staffing 
levels, exerts a negative effect on enrollment. A one standard deviation reduction in waiting time $(28 \mathrm{~min})$ is associated with a 14 percentage point increase in enrollment.

The importance of the quality of care in determining insurance uptake and use of services also emerged from the focus group discussions. Both insured and uninsured FGD participants from all regions criticized the quality of available services and indicated that even if public health facilities were relatively accessible in terms of distance as compared to private facilities, a number of them did not have the necessary laboratory equipment and medicines. In relation to this, an insured FGD participant in the Amhara region shared her experience,

I went to private providers and incurred OOP health care expenditure even if I am a CBHI member. The health center in our village did not have laboratory equipment and the health workers could not examine my real health problem

[Discussed on January 11, 2013]

An additional issue which we cannot control for in our estimates but was revealed by the qualitative information is the reported behavior and attitude of medical providers to those who have insurance. For instance, an insured FGD participant in SNNPR explained,

The health professionals do not provide equal services and respect for both insured and uninsured patients. They give medicine only for non-members of the scheme and they tell members of the scheme to buy from private stores and we are forced to buy drugs from our pockets even if we have health insurance cards

[Discussed on January 24, 2013]

Similarly, uninsured FGD participants in the Oromiya region believed,

The doctors give priority to those patients who pay in cash during services provision and insured people do not get quick services. Moreover, they do not want to properly treat insured patients and think that most insured people come to the health facility just for a check up for minor medical cases since CBHI members do not pay cash during services utilization

[Discussed on December 25, 2013]

Based on the FGD the two reasons for the preferential treatment meted out to uninsured patients is their immediate contribution to the revenues of the health facilities and their apparent overuse of health care facilities. Doctors/facilities may also prefer to treat the uninsured due to the paper work required to receive payments for insured patients and the payment lag. 22

Households in the Amhara and Oromiya regions are about 20-22 percentage points more likely to enroll as compared to households living in Tigray and SNNPR. A possible reason behind the lower CBHI participation in the SNNPR region, at least initially, could be the relative difference in the design characteristics of the schemes. Unlike the three pilot sites, CBHI members in SNNPR have limited access to tertiary health care services. Insured households in this region may only use tertiary services at the nearest public hospital (while those in Amhara may visit any public hospital within the region and those in Oromiya may use care from public hospitals within and outside the region). Similarly, unlike the other three regions, insured households in SNNPR cannot claim reimbursements if they use health care services from private providers in the event that medical equipment or drugs are not available in CBHI-linked facilities. In addition, SNNPR is a relatively poorer province (see Appendix D, consumption quintiles) and the lower uptake may also reflect a lower capacity to pay for health insurance. Despite low uptake in April 2012 potentially due to the reasons discussed above, by December 2012 enrollment in the region had caught up with the leading region in the country. In the case of Tigray, while the features of the insurance package do not differ as compared to other regions it lacks behind in terms of the quality of care and records the longest waiting times across regions and is also not particularly well-resourced in terms of equipment (see Appendix D). ${ }^{23}$

\section{CONCLUSION}

This paper used data from longitudinal household surveys, a health facility survey, and qualitative information obtained through focus group discussions and key informant interviews to analyze the factors that determine insurance uptake in a pilot CBHI scheme introduced by the Ethiopian government in June 2011. The paper focused on three issues - whether the scheme is socially inclusive, whether uptake is more likely among households with specific health care status and health needs, and the role of the quality of health care in influencing uptake.

We found that by December 2012, a year and a half since being introduced, scheme uptake had reached an impressive $45.5 \%$ of target households. This is relatively high compared to the experiences of other Sub-Saharan African countries which have introduced similar schemes. With regard to social inclusion, unlike the bulk of the literature which finds that the lowest income groups are often excluded from such schemes we found that the CBHI scheme may be characterized as pro-poor. There was no statistically significant evidence that socioeconomic status as measured by consumption quintiles and education of the household head directly influences enrollment. Rather, we found that food-insecure households who have participated or still participate in the productive safety net program (PSNP) are far more likely (31 percentage points) to join the pilot scheme. The inclusive nature of the scheme may also be due to the relatively low premiums $(2-3 \%$ of household monthly income) supported by the central government's subsidy program. With regard to the PSNP, the KII and the FGD revealed that the government is making efforts to integrate various development interventions and recipients of one government program are far more likely to be informed about other government programs which in turn encourages uptake. The positive effect of interlinking different programs on uptake is also discernible in the literature, and several studies find that insurance schemes that have been linked to existing microcredit programs tend to be associated with higher uptake (Mebratie et al., 2013). ${ }^{24}$ However, the flip side of this interlinking is evidence of officials coercing PSNP beneficiaries to join the scheme. Although dropping such households from the analysis did not lead to substantial changes in the estimates, about $10 \%$ of insured households indicated that they had been pressurized into joining the scheme.

Self-assessed health status and past illnesses and symptoms are not positively correlated with uptake and about $8 \%$ of insured households indicated that the main reason for enrolling in the scheme is that household members are frequently ill. Given these figures it is unlikely that adverse selection will seriously afflict the scheme. An explanation for this may be the scheme design which was explicitly designed to mitigate adverse selection by permitting enrollment only at the household level.

A relatively novel contribution of the paper is our examination of the role of the quality of care on uptake. The availability of medical equipment and waiting time to see a medical professional, played a large role in determining enrollment. For instance, the availability of blood-testing equipment at the nearest health center was associated with a 30 percentage point increase in enrollment while a one standard deviation reduction in waiting time was associated with a 14 percentage point 
increase in uptake. During the FGD both insured and non-insured groups criticized the shortage of medical equipment, lack of drugs, and also pointed out that health providers favored uninsured patients versus the insured. The proximate reasons for this appear to be the immediate payments provided by the uninsured and the administrative burden associated with obtaining payments for providing services to the insured.

The start of the pilot scheme has seen an impressive enrollment rate, and despite coercion in some cases and criticisms about the quality of care, a clear signal of the benefits emanating from the scheme is that almost all insured households $(96 \%)$ indicate that they will renew their membership (see Table 5). At the same time about $57 \%$ of uninsured households state that they plan to enroll in the future. While this augurs well as the government plans to spread the scheme to an additional 161 districts which fulfill the same selection criteria as the 12 pilot districts, the results presented here suggest that expanding uptake will need continued investments in the quality of care and attempts to alter the differential treatment received by the insured.

From an international perspective the high uptake in a relatively short span of time, especially as compared to other schemes in Sub-Saharan Africa and with limited evidence of social exclusion, highlights the potentially positive design features of the Ethiopian scheme. Our assessment based on the empirical evidence presented here, a discussion with key informants and a comparison with the existing body of work on such schemes, yields two especially noteworthy points on scheme design. First, the current scheme (which may be characterized as a government run but community-involved scheme) is embedded within existing government structures and scheme performance and uptake is one of the yardsticks on the basis of which the success of a kebele's administration is measured. Second, interlinking CBHI schemes with other social programs, such as the PSNP, and using this as a platform to spread information and scheme awareness appears to be a successful strategy. While other aspects such as the relatively low cost of the scheme cannot be ignored, embedding and basing administrative performance on the basis of scheme performance and interlinking the scheme with pre-existing programs tend to stand out. Whether such features can be incorporated in schemes in other countries is an open question but they have clearly played a role in enhancing the performance of the current scheme.

\section{NOTES}

1. CBHIs are non-profit organizations which are built upon the principles of social solidarity and common benefits to create accessible health care services and provide financial protection against out-of-pocket health expenditure. Such schemes are mostly characterized by voluntary membership and the target community is expected to involve in resource mobilization and allocation activities. The schemes apply the basic principles of formal insurance by pooling resources and sharing the financial risks of health shocks (Ahuja \& Jütting, 2004; Bhattamishra \& Barrett, 2010; Sinha, Ranson, \& Mills, 2007).

2. Mebratie et al. (2013) report that of the fourteen papers which examine social exclusion in CBHI uptake using regression methods, only two studies are based on longitudinal data sets canvassed before and after the intervention. The remainder are cross-section studies based on post-intervention data. Similarly, only three out of nine papers that have examined adverse selection rely on longitudinal data.

3. We reviewed 17 papers, since 2001 , that have estimated enrollment in CBHI schemes based on regression analysis. Our assessment shows that only 2 of the 17 papers (Thornton, Hatt, Field, Islam, Solís Diaz, \& González, 2010; Vellakkal, 2013) also use qualitative data, only 1 (Gnawali et al.,2009) out of 17 control for quality of health care and 1 (Thornton et al., 2010) out of 17 regresses current enrollment on last period traits, the rest regress current enrollment on current traits, including current health status.

4. The initial plan was to roll out the pilot scheme in three districts in each of the four regions. However, an additional district in the Oromiya region volunteered to join the pilot scheme and was included.

5. The complete set of selection criteria included (1) willingness of district authorities to implement the schemes, (2) commitment of districts to support schemes, (3) geographical accessibility of health centers, (4) quality of health centers, (5) the implementation of cost recovery, local revenue retention, and public pharmacy policies in health centers. This last condition is one component of the set of health care financing reforms (HCFR) that have been under implementation since 1998. Essentially, districts where the CBHI was offered should have taken measures to increase cost recovery and retain locally raised revenues. This means that health facilities are free to add a mark-up of up to $25 \%$ on the cost price of the drugs that they sell and a $25 \%$ markup on laboratory and other services. Facilities are expected to retain these revenues and to use them to improve the quality of their services. For more details see USAID. (2011). Since all health facilities in the pilot district have implemented this sub-component any variations in service quality due to this measure are expected to be manifested through the quality of health care.

6. In their review of the CBHI literature, Mebratie et al. (2013) classify the 48 schemes covered in the studies they review into three distinct scheme types. Sixteen are community prepayment health organizations, seven are health care provider-initiated insurance schemes, and 25 are classified as government-run community-involved health insurance schemes. The Ethiopian CBHI scheme falls in the last category.

7. According to information obtained from a key informant at Abt Associates, no village voted against the scheme and the program rolled out in all villages in the pilot districts.

8. Core household members include a mother, father, and their children below age 18 .

9. This figure is based on an annual per capita income of USD 340 in 2011, an exchange rate of ETB 18 to USD 1 and a household of six core members. As compared to other similar schemes in Africa, the costs for an entire household to enroll in the Ethiopian scheme lies at the lower end of the cost spectrum. For example, schemes in Burkina Faso (Parmar, Reinhold, Souares, Savadogo, \& Sauerborn, 2012), Ghana (Mensah, Oppong, \& Schmidt, 2010), and Nigeria (Onwujekwe, Onoka, Uzochukwu, Okoli, Obikeze, \& Eze, 2009) are more expensive while schemes in Mail (Franco, Diop, Burgert, Kelley, Makinen, \& Simpara, 2008) and Rwanda (Saksena, Antunes, Xu, Musango, \& Carrin, 2011) are as costly as the Ethiopian scheme.

10. Indigent groups are defined as those households which do not have land, a house, or any valuable assets. In December 2012, the share of indigent groups as a proportion of the total eligible households $(300,605$ households) ranged from a low of $0.9 \%$ in the Deder district in Oromiya to $21.1 \%$ in the South Achefer district in the Amhara region. Nation-wide, by December 2012, $8.9 \%$ of total eligible households had received a fee-waiver. The guidelines state that $10 \%$ of the poorest households 
would receive a fee waiver. However, the data presented in Table 2 shows substantial differences across regions. Our investigation of this issue shows that the higher share of non-paying beneficiaries is due to differences in funding arrangements across regions. In the regions with the larger number of non-paying beneficiaries the regional governments, which have greater financial capacity, provide the bulk of financing while in the regions with a low number of non-paying beneficiaries the district governments are expected to provide financing. For instance, in the Tigray region, $70 \%$ of the resources are provided by the regional government; it is $90 \%$ in the Amhara region and in Oromiya and SNNPR regions, the district governments are responsible for $100 \%$ of the subsidy.

11. The qualitative survey shows that the participation of the community in the decision-making process of the scheme is limited. Only two CBHI members were actually selected as part of the village management and there were no regular meetings with the community to update members about the activities of the scheme and collect feedback.

12. In each of the four regions there are three $\mathrm{CBHI}$ districts and one control district.

13. In total, the second round of the survey covered 1,599 ( $2 \%$ attrition) households that had been canvassed in the first round.

\section{On average about 41 households were matched to one health center.}

15. The productive safety net program (PSNP) is a government social security program designed to support chronically food-insecure households in food-insecure districts. Participants engage in public works (road and school construction, soil, and water conservation) and receive payments in cash or food.

16. Since we are interested in identifying the separate effect of health care expenditure the consumption measure used here is net of health care expenditure.

17. Iqqub is a rotating credit and savings association.
18. Wonfel \& Debo are traditional associations involving informal labor sharing arrangements in agricultural activities.

19. "Perceived quality of health care services" is based on eliciting the view of the head of the health facility survey on the overall quality of health care services provided by the facility. The specific question was, in general, do you think that this health center is providing the expected standard of health care services, yes or no.

20. A majority $(55 \%)$ of the PSNP beneficiaries fall in the bottom two quintiles of the consumption distribution.

21. In our data set about $3.5 \%$ of enrolled households receive a fee-waiver. Dropping these households from the analysis does not lead to any substantial changes in the estimates (see Appendix B).

22. Health facilities are expected to submit claims on a quarterly basis. To be reimbursed, health facilities need to submit a claim based on a specific format and submit it to the district CBHI offices. Photocopies of the signatures of CBHI members who used health care services also need to be attached. The district CBHI offices are supposed to pay $75 \%$ of the claims within three days of receipt of the forms by checks/bank transfer without any investigation. Prior to paying out the remainder, a medical audit is expected to be conducted. Once approved, the rest of the claims are paid out.

23. While there is a link between regions and the quality of care on offer, the region fixed effects pick up a number of other factors (quality of administration, willingness to support the scheme, regional differences in resources) and not just the quality of care and hence we include both sets of regressors. However, we have estimated specifications without the inclusion of the regional fixed effects (see Appendix E). The effects of the quality of health care measures are not influenced by this omission, suggesting that the two sets of variables pick up different effects.

24. For instance, see Ranson (2002), Dror et al. (2009), and Ranson et al. (2006).

\section{REFERENCES}

Abt Associates Inc. (2013). Health financing reform in Ethiopia: Results and progress to date. Addis Ababa: Abt Associates Inc..

Ahuja, R., \& Jütting, J. (2004). Are the poor too poor to demand health insurance?. Journal of MicrofinancelESR Review, 6(1), 1-20.

Bhattamishra, R., \& Barrett, C. B. (2010). Community-based risk management arrangements: A review. World Development, 38(7), 923-932.

Chankova, S., Sulzbach, S., \& Diop, F. (2008). Impact of mutual health organizations: Evidence from West Africa. Health Policy and Planning, 23(4), 264-276.

Chetty, R., \& Looney, A. (2006). Consumption smoothing and the welfare consequences of social insurance in developing economies. Journal of Public Economics, 90(12), 2351-2356.

De Allegri, M., Kouyaté, B., Becher, H., Gbangou, A., Pokhrel, S., Sanon, M., et al. (2006). Understanding enrolment in community health insurance in Sub-Saharan Africa: A population-based casecontrol study in rural Burkina Faso. Bulletin of the World Health Organization, 84(11), 852-858.

Dekker, M., \& Wilms, A. (2010). Health insurance and other risk-coping strategies in Uganda: The case of microcare insurance ltd. World Development, 38(3), 369-378.

Dercon, S. (2002). Income risk, coping strategies, and safety nets. The World Bank Research Observer, 17(2), 141-166.

Diop, F., Sulzbach, S., \& Chankova, S. (2006). The impact of mutual health organizations on social inclusion, access to health care and household income protection: Evidence from Ghana, Senegal and Mali. Bethesda. MD: PHRplus, Abt Associates Inc. Retrieved from http:// pdf.usaid.gov/pdf_docs/Pnadh424.pdf.
Donfouet, H. P. P., \& Mahieu, P. (2012). Community-based health insurance and social capital: A review. Health Economics Review, 2(1), $1-5$.

Dror, D. M., Radermacher, R., Khadilkar, S. B., Schout, P., Hay, F. X., Singh, A., et al. (2009). Microinsurance: Innovations in low-cost health insurance. Health Affairs (Project Hope), 28(6), $1788-1798$.

Ekman, B. (2004). Community-based health insurance in low-income countries: A systematic review of the evidence. Health Policy and Planning, 19(5), 249-270.

FMoH (2010). Health Sector Development Programme IV: 2010/11-2014/ 15. Retrieved from http://phe-ethiopia.org/admin/uploads/.

FMoH (2011). Health and Health Related Indicators for 2003 EC (2011 $G C)$. Retrieved from http://www.cnhde.org.et/wp-content/uploads/ 2013/04/Ind 2003.pdf.

Franco, L. M., Diop, F. P., Burgert, C. R., Kelley, A. G., Makinen, M., \& Simpara, C. H. T. (2008). Effects of mutual health organizations on use of priority health-care services in urban and rural Mali: A case-control study. Bulletin of the World Health Organization, 86(11), 830-838.

Gnawali, D. P., Pokhrel, S., Sié, A., Sanon, M., De Allegri, M., Souares, A., et al. (2009). The effect of community-based health insurance on the utilization of modern health care services: Evidence from Burkina Faso. Health Policy, 90(2), 214-222.

Jakab, M., \& Krishnan, C. (2001). Community involvement in health care financing: Impact, strengths and weaknesses: A synthesis of literature. Retrieved from https://openknowledge.worldbank.org/handle/10986/ 13706. 
Jütting, J. P. (2004). 'Do community-based health insurance schemes improve poor people's access to health care? Evidence from Rural Senegal'. World Development, 32(2), 273-288.

Mebratie, A. D., Sparrow, R., Alemu, G., \& Bedi, A. S. (2013) Community-based health insurance schemes: A systematic review (ISS Working Paper No 568). The Hague: International Institute of Social Studies of Erasmus University Rotterdam. Retrieved from http:// repub.eur.nl/pub/50087.

Mensah, J., Oppong, J. R., \& Schmidt, C. M. (2010). Ghana's national health insurance scheme in the context of the health MDGs: An empirical evaluation using propensity score matching. Health Economics, 19(S1), 95-106.

Mladovsky, P., \& Mossialos, E. (2008). A conceptual framework for community-based health insurance in low-income countries: Social capital and economic development. World Development, 36(4), 590-607.

Nketiah-Amponsah, E. (2009). Demand for health insurance among women in Ghana: Cross-sectional evidence. International Research Journal of Finance and Economics, 1(33), 179-191.

Onwujekwe, O., Onoka, C., Uzochukwu, B., Okoli, C., Obikeze, E., \& Eze, S. (2009). Is community-based health insurance an equitable strategy for paying for healthcare? Experiences from Southeast Nigeria. Health Policy, 92(1), 96-102.

Palmer, M. G. (2014). Inequalities in universal health coverage: Evidence from Vietnam. World Development, 64, 384-394.

Parmar, D., Reinhold, S., Souares, A., Savadogo, G., \& Sauerborn, R. (2012). Does Community-Based health insurance protect household assets? Evidence from rural Africa. Health Services Research, 47(2), 819-839.

Preker, A. S., Carrin, G., Dror, D., Jakab, M., Hsiao, W., \& ArhinTenkorang, D. (2002). Effectiveness of community health financing in meeting the cost of illness. Bulletin of the World Health Organization, $80(2), 143-150$

Ranson, M. K. (2002). Reduction of catastrophic health care expenditures by a community-based health insurance scheme in Gujarat, India: Current experiences and challenges. Bulletin of the World Health Organization, 80(8), 613-621.
Ranson, M. K., Sinha, T., Chatterjee, M., Acharya, A., Bhavsar, A., Morris, S. S., et al. (2006). Making health insurance work for the poor: Learning from the self-employed women's association's (SEWA) community-based health insurance scheme in India. Social Science \& Medicine, 62(3), 707-720.

Saksena, P., Antunes, A. F., Xu, K., Musango, L., \& Carrin, G. (2011). Mutual health insurance in Rwanda: Evidence on access to care and financial risk protection. Health Policy, 99(3), 203-209.

Schneider, P. (2004). Why should the poor insure? Theories of decisionmaking in the context of health insurance. Health Policy and Planning, 19(6), 349-355.

Shimeles, A. (2010). Community based health insurance schemes in Africa: The case of Rwanda (GU Working Papers 463). Göteborg: Göteborg University. Retrieved from https://gupea.ub.gu.se/handle/2077/23064.

Sinha, T., Ranson, M. K., \& Mills, A. J. (2007). Protecting the poor? The distributional impact of a bundled insurance scheme. World Development, 35(8), 1404-1421.

Smith, K. V., \& Sulzbach, S. (2008). Community-based health insurance and access to maternal health services: Evidence from three West African countries. Social Science \& Medicine, 66(12), 2460-2473.

Thornton, R. L., Hatt, L. E., Field, E. M., Islam, M., Solís Diaz, F., \& González, M. A. (2010). Social security health insurance for the informal sector in Nicaragua: A randomized evaluation. Health Economics, 19(S1), 181-206.

USAID. (2011). Ethiopia Health Sector Financing Reform. Retrieved from http://pdf.usaid.gov/pdf_docs/pdact293.pdf.

Vellakkal, S. (2013). Determinants of enrolment in voluntary health insurance: Evidences from a mixed method study, Kerala, India. Journal of Financial Research, 4(2), 99-197.

Table 6. Description of explanatory variables

\begin{tabular}{|c|c|}
\hline Variable & Description \\
\hline \multicolumn{2}{|l|}{ Socioeconomic status } \\
\hline Consumption quintiles & $\begin{array}{l}\text { Classification of households based on monthly household consumption expenditure (in Birr) excluding } \\
\text { health care spending (poorest quintile, 2nd quintile, 3rd quintile, 4th quintile, richest quintile) }\end{array}$ \\
\hline Participated in PSNP & Household participated or still participates in productive safety net program, PSNP ( $1=$ yes $)$ \\
\hline \multicolumn{2}{|l|}{ Demographic traits } \\
\hline Male-headed hhd. & Male-headed household $(1=$ yes $)$ \\
\hline Prop. of children aged under 6 & Proportion of children in the household aged under 6 years \\
\hline Prop. of male aged $6-15$ & Proportion of males in the household aged between 6 and 15 years \\
\hline Prop. of female aged $6-15$ & Proportion of females in the household aged between 6 and 15 years \\
\hline Prop. of male aged $16-64$ & Proportion of males in the household aged between 16 and 64 years \\
\hline Prop. of female aged 16-64 & Proportion of females in the household aged between 16 and 64 years \\
\hline Prop. of elderly aged above 64 & Proportion of elderly in the household aged above 64 years \\
\hline Prop. of hhd members with poor SAH & $\begin{array}{l}\text { Proportion of household members aged } 6 \text { years and above with poor self-assessed health status (based on } \\
\text { the perception of the respondent to the household survey) }\end{array}$ \\
\hline Past illness event & Household, total number of days ill past two months \\
\hline Chronic disease & $\begin{array}{l}\text { Number of household members aged } 6 \text { and above years who suffered from a chronic disease (symptoms } \\
\text { have been going on for more than } 30 \text { days) }\end{array}$ \\
\hline Outpatient care use & At least one household member used outpatient care in the past two months $(1=$ yes $)$ \\
\hline Inpatient care use & At least one household member used inpatient care in the past twelve months $(1=$ yes $)$ \\
\hline Outpatient healthcare expenditure & Household's health care spending (in Birr) for outpatient care in the past two months \\
\hline Inpatient healthcare expenditure & Household's health care spending (in Birr) for inpatient care in the past twelve months \\
\hline Trust in modern heath care & $\begin{array}{l}\text { Modern health care providers can be trusted more than traditional healers (perception of the respondent } \\
\text { to the household survey) (agree, not agree) }\end{array}$ \\
\hline
\end{tabular}

\section{APPENDIX A}


Table 6 (continued)

\begin{tabular}{|c|c|}
\hline Variable & Description \\
\hline \multicolumn{2}{|c|}{ Formal and informal access to credit and networks } \\
\hline Member of Iqqub & At least one household member participates in an Iqqub association ( $1=$ yes $)$ \\
\hline Member of credit \& savings ass. & At least one household member participates in credit and savings association $(1=$ yes $)$ \\
\hline Member of religious group & At least one household member participates in a religious group $(1=$ yes $)$ \\
\hline Participates in Wonfel or Debo & At least one household member participates in Wonfel or Debo $(1=$ yes $)$ \\
\hline Savings in bank account & At least one household member has savings in a bank account ( $1=$ yes $)$ \\
\hline Outstanding loan & The household has an outstanding loan $(1=$ yes $)$ \\
\hline Some one to rely on & The household has someone to rely on at times of shock $(1=$ yes $)$ \\
\hline Official position held & At least one household member held or still holds official, kebele, or traditional position $(1=$ yes $)$ \\
\hline \multicolumn{2}{|l|}{ Supply side characteristics } \\
\hline Travel time to health center & Travel time to the nearest health center (in minutes) \\
\hline Travel time to public hospital & Travel time to the nearest public hospital (in minutes) \\
\hline Completed first degree $(12+3)$ & Head of the facility has at least completed a first medical degree $(12+3)(1=$ yes $)$ \\
\hline Received on the job training & Head of the facility received on the job training $(1=$ yes $)$ \\
\hline Availability of blood-testing equipment & The health facility has blood-testing equipment ( $1=$ yes) \\
\hline Availability of urine-testing equipment & The health facility has urine-testing equipment $(1=$ yes $)$ \\
\hline Waiting time to get patient card & $\begin{array}{l}\text { Average waiting time (in minutes) before getting patient card (based on the response of five patients } \\
\text { interviewed after getting medical treatment from the health facility) }\end{array}$ \\
\hline Waiting time to see a medical professional & $\begin{array}{l}\text { Average waiting time (in minutes) to see a medical professional (Doctor, nurse) (based on the response of } \\
\text { five patients interviewed after getting medical treatment from the health facility) }\end{array}$ \\
\hline Perceived quality of care & $\begin{array}{l}\text { Perception of the respondent (typically the head of the facility) about the overall quality of health care } \\
\text { services provided by the facility ( } 1=\text { yes, the facility provides quality services) }\end{array}$ \\
\hline \multicolumn{2}{|l|}{ Community characteristics } \\
\hline Region & $\begin{array}{l}\text { The region where the household is located (Tigray Region, Amhara Region, Oromiya Region, Southern } \\
\text { Nations Nationalities and People's Region/SNNPR) }\end{array}$ \\
\hline
\end{tabular}

\section{APPENDIX B}

Table 7. Probability of enrollment-marginal effects (std. error) (excluding non-fee paying)

\begin{tabular}{|c|c|c|c|c|}
\hline Variables & Model 1 & Model 2 & Model 3 & Model 4 \\
\hline \multicolumn{5}{|l|}{ Socioeconomic status } \\
\hline 2nd consumption quintile (ref: poorest consumption quintile) & $\begin{array}{c}0.0126 \\
(0.0527)\end{array}$ & $\begin{array}{c}0.0177 \\
(0.0537)\end{array}$ & $\begin{array}{c}0.0150 \\
(0.0532)\end{array}$ & $\begin{array}{c}0.0190 \\
(0.0539)\end{array}$ \\
\hline 3rd consumption quintile & $\begin{array}{c}0.0361 \\
(0.0548)\end{array}$ & $\begin{array}{c}0.0442 \\
(0.0560)\end{array}$ & $\begin{array}{c}0.0388 \\
(0.0553)\end{array}$ & $\begin{array}{c}0.0452 \\
(0.0560)\end{array}$ \\
\hline 4th consumption quintile & $\begin{array}{c}0.0480 \\
(0.0557)\end{array}$ & $\begin{array}{c}0.0477 \\
(0.0549)\end{array}$ & $\begin{array}{c}0.0474 \\
(0.0556)\end{array}$ & $\begin{array}{c}0.0459 \\
(0.0547)\end{array}$ \\
\hline Richest consumption quintile & $\begin{array}{c}0.0886 \\
(0.0727)\end{array}$ & $\begin{array}{c}0.0912 \\
(0.0738)\end{array}$ & $\begin{array}{c}0.0886 \\
(0.0732)\end{array}$ & $\begin{array}{c}0.0912 \\
(0.0725)\end{array}$ \\
\hline HH head education-Informal (ref: no education at all) & $\begin{array}{c}0.0141 \\
(0.0511)\end{array}$ & $\begin{array}{c}0.0121 \\
(0.0505)\end{array}$ & $\begin{array}{c}0.0119 \\
(0.0511)\end{array}$ & $\begin{array}{l}0.00747 \\
(0.0501)\end{array}$ \\
\hline HH head education-Primary or above & $\begin{array}{c}0.0375 \\
(0.0457)\end{array}$ & $\begin{array}{c}0.0388 \\
(0.0457)\end{array}$ & $\begin{array}{c}0.0365 \\
(0.0456)\end{array}$ & $\begin{array}{c}0.0328 \\
(0.0459)\end{array}$ \\
\hline Participated in PSNP & $\begin{array}{l}0.322^{* * *} \\
(0.0666)\end{array}$ & $\begin{array}{l}0.326^{* * *} \\
(0.0670)\end{array}$ & $\begin{array}{l}0.322^{* * *} \\
(0.0668)\end{array}$ & $\begin{array}{l}0.333^{* * *} \\
(0.0667)\end{array}$ \\
\hline \multicolumn{5}{|l|}{ Demographic traits } \\
\hline Male-headed $\mathrm{HH}$ & $\begin{array}{c}0.0229 \\
(0.0526)\end{array}$ & $\begin{array}{c}0.0251 \\
(0.0512)\end{array}$ & $\begin{array}{c}0.0228 \\
(0.0522)\end{array}$ & $\begin{array}{c}0.0263 \\
(0.0511)\end{array}$ \\
\hline Age of HH head & $\begin{array}{c}0.00134 \\
(0.00175)\end{array}$ & $\begin{array}{c}0.00129 \\
(0.00175)\end{array}$ & $\begin{array}{c}0.00132 \\
(0.00175)\end{array}$ & $\begin{array}{c}0.00139 \\
(0.00177)\end{array}$ \\
\hline Household size & $\begin{array}{l}0.0261^{* * *} \\
(0.00961)\end{array}$ & $\begin{array}{l}0.0258^{* * *} \\
(0.00971)\end{array}$ & $\begin{array}{l}0.0259^{* * *} \\
(0.00975)\end{array}$ & $\begin{array}{c}0.0244^{* *} \\
(0.00976)\end{array}$ \\
\hline Prop. of children aged under 6 (ref: Prop. of male aged 16-64) & $\begin{array}{c}-0.0706 \\
(0.175)\end{array}$ & $\begin{array}{c}-0.0819 \\
(0.174)\end{array}$ & $\begin{array}{c}-0.0763 \\
(0.174)\end{array}$ & $\begin{array}{c}-0.0446 \\
(0.178)\end{array}$ \\
\hline Prop. of male aged $6-15$ & $\begin{array}{c}0.00328 \\
(0.162)\end{array}$ & $\begin{array}{c}0.00154 \\
(0.161)\end{array}$ & $\begin{array}{c}0.000774 \\
(0.162)\end{array}$ & $\begin{array}{l}0.0252 \\
(0.162)\end{array}$ \\
\hline Prop. of female aged $6-15$ & $\begin{array}{c}0.125 \\
(0.165)\end{array}$ & $\begin{array}{c}0.118 \\
(0.162)\end{array}$ & $\begin{array}{c}0.114 \\
(0.164)\end{array}$ & $\begin{array}{c}0.137 \\
(0.164)\end{array}$ \\
\hline
\end{tabular}


Table 7 (continued)

\begin{tabular}{|c|c|c|c|c|}
\hline Variables & Model 1 & Model 2 & Model 3 & Model 4 \\
\hline Prop. of female aged 16-64 & $\begin{array}{c}-0.0144 \\
(0.183)\end{array}$ & $\begin{array}{c}-0.0223 \\
(0.183)\end{array}$ & $\begin{array}{c}-0.0192 \\
(0.182)\end{array}$ & $\begin{array}{c}0.000296 \\
(0.183)\end{array}$ \\
\hline Prop. of elderly aged above 64 & $\begin{array}{l}-0.248 \\
(0.156)\end{array}$ & $\begin{array}{l}-0.235 \\
(0.153)\end{array}$ & $\begin{array}{l}-0.249 \\
(0.153)\end{array}$ & $\begin{array}{l}-0.224 \\
(0.161)\end{array}$ \\
\hline HH head religion-Orthodox Christian (ref: Muslim) & $\begin{array}{c}0.122^{*} \\
(0.0725)\end{array}$ & $\begin{array}{c}0.119^{*} \\
(0.0723)\end{array}$ & $\begin{array}{c}0.122^{*} \\
(0.0726)\end{array}$ & $\begin{array}{c}0.130^{*} \\
(0.0726)\end{array}$ \\
\hline HH head religion-Protestant & $\begin{array}{l}0.0835 \\
(0.102)\end{array}$ & $\begin{array}{l}0.0819 \\
(0.103)\end{array}$ & $\begin{array}{l}0.0853 \\
(0.102)\end{array}$ & $\begin{array}{l}0.0890 \\
(0.103)\end{array}$ \\
\hline HH head religion-Other religion or no religion & $\begin{array}{c}-0.0795 \\
(0.120)\end{array}$ & $\begin{array}{c}-0.0844 \\
(0.117)\end{array}$ & $\begin{array}{c}-0.0815 \\
(0.119)\end{array}$ & $\begin{array}{c}-0.0617 \\
(0.123)\end{array}$ \\
\hline \multicolumn{5}{|l|}{ Health status and health care use } \\
\hline Prop. of household members with poor SAH (ref: Prop. of household members with good SAH) & $\begin{array}{l}-0.0596 \\
(0.0556)\end{array}$ & $\begin{array}{l}-0.0685 \\
(0.0532)\end{array}$ & $\begin{array}{l}-0.0625 \\
(0.0550)\end{array}$ & $\begin{array}{l}-0.0821 \\
(0.0531)\end{array}$ \\
\hline Past illness event & $\begin{array}{c}0.00114 \\
(0.00103)\end{array}$ & & $\begin{array}{c}0.00104 \\
(0.00115)\end{array}$ & \\
\hline Chronic illness & $\begin{array}{l}-0.0254 \\
(0.0212)\end{array}$ & & $\begin{array}{l}-0.0247 \\
(0.0213)\end{array}$ & \\
\hline Outpatient care use & & $\begin{array}{c}0.0259 \\
(0.0327)\end{array}$ & $\begin{array}{c}0.0187 \\
(0.0369)\end{array}$ & \\
\hline Inpatient care use & & $\begin{array}{l}-0.0767 \\
(0.0801)\end{array}$ & $\begin{array}{l}-0.0804 \\
(0.0796)\end{array}$ & \\
\hline Outpatient healthcare expenditure & & & & $\begin{array}{c}0.000243^{* *} \\
(0.000112)\end{array}$ \\
\hline Inpatient healthcare expenditure & & & & $\begin{array}{l}-3.16 \mathrm{e}-05 \\
(2.52 \mathrm{e}-05)\end{array}$ \\
\hline Trust in modern care-Agree (ref: Not agree) & $\begin{array}{c}0.0858 \\
(0.0574)\end{array}$ & $\begin{array}{c}0.0859 \\
(0.0573)\end{array}$ & $\begin{array}{c}0.0854 \\
(0.0573)\end{array}$ & $\begin{array}{c}0.0848 \\
(0.0580)\end{array}$ \\
\hline \multicolumn{5}{|l|}{ Formal and informal access to credit and social networks } \\
\hline Member of Iqqub & $\begin{array}{c}0.0622 \\
(0.0782)\end{array}$ & $\begin{array}{c}0.0670 \\
(0.0770)\end{array}$ & $\begin{array}{c}0.0621 \\
(0.0778)\end{array}$ & $\begin{array}{c}0.0731 \\
(0.0760)\end{array}$ \\
\hline Member of credit and savings association & $\begin{array}{c}0.0195 \\
(0.0667)\end{array}$ & $\begin{array}{c}0.0160 \\
(0.0666)\end{array}$ & $\begin{array}{c}0.0175 \\
(0.0663)\end{array}$ & $\begin{array}{c}0.0168 \\
(0.0681)\end{array}$ \\
\hline Member of religious group & $\begin{array}{c}0.0357 \\
(0.0389)\end{array}$ & $\begin{array}{c}0.0378 \\
(0.0382)\end{array}$ & $\begin{array}{c}0.0346 \\
(0.0387)\end{array}$ & $\begin{array}{c}0.0361 \\
(0.0379)\end{array}$ \\
\hline Participate in Wonfel or Debo & $\begin{array}{c}0.0381 \\
(0.0450)\end{array}$ & $\begin{array}{c}0.0376 \\
(0.0446)\end{array}$ & $\begin{array}{c}0.0358 \\
(0.0451)\end{array}$ & $\begin{array}{c}0.0412 \\
(0.0451)\end{array}$ \\
\hline Savings in bank account & $\begin{array}{c}0.0494 \\
(0.0605)\end{array}$ & $\begin{array}{c}0.0483 \\
(0.0594)\end{array}$ & $\begin{array}{c}0.0509 \\
(0.0591)\end{array}$ & $\begin{array}{c}0.0454 \\
(0.0605)\end{array}$ \\
\hline Outstanding loan & $\begin{array}{c}0.0684 \\
(0.0502)\end{array}$ & $\begin{array}{c}0.0692 \\
(0.0502)\end{array}$ & $\begin{array}{c}0.0668 \\
(0.0503)\end{array}$ & $\begin{array}{c}0.0706 \\
(0.0507)\end{array}$ \\
\hline Someone to rely on & $\begin{array}{l}-0.0125 \\
(0.0288)\end{array}$ & $\begin{array}{l}-0.0161 \\
(0.0293)\end{array}$ & $\begin{array}{l}-0.0129 \\
(0.0290)\end{array}$ & $\begin{array}{l}-0.0154 \\
(0.0292)\end{array}$ \\
\hline Official position held & $\begin{array}{l}0.114^{* * *} \\
(0.0436)\end{array}$ & $\begin{array}{l}0.113^{* * *} \\
(0.0436)\end{array}$ & $\begin{array}{l}0.115^{* * *} \\
(0.0441)\end{array}$ & $\begin{array}{c}0.107^{* *} \\
(0.0423)\end{array}$ \\
\hline Supply side characteristics & & & & \\
\hline Travel time to health center & $\begin{array}{l}0.000920^{* *} \\
(0.000386)\end{array}$ & $\begin{array}{l}0.000962^{* *} \\
(0.000391)\end{array}$ & $\begin{array}{l}0.000950^{* *} \\
(0.000389)\end{array}$ & $\begin{array}{l}0.000952^{* *} \\
(0.000395)\end{array}$ \\
\hline Travel time to public hospital & $\begin{array}{c}3.68 \mathrm{e}-05 \\
(0.000331)\end{array}$ & $\begin{array}{c}4.48 \mathrm{e}-05 \\
(0.000333)\end{array}$ & $\begin{array}{c}2.89 \mathrm{e}-05 \\
(0.000332)\end{array}$ & $\begin{array}{c}7.58 \mathrm{e}-05 \\
(0.000334)\end{array}$ \\
\hline Completed first degree $(12+3)$ & $\begin{array}{l}-0.115 \\
(0.0731)\end{array}$ & $\begin{array}{l}-0.116 \\
(0.0725)\end{array}$ & $\begin{array}{l}-0.115 \\
(0.0731)\end{array}$ & $\begin{array}{l}-0.121^{*} \\
(0.0734)\end{array}$ \\
\hline Received on the job training & $\begin{array}{l}-0.0394 \\
(0.0887)\end{array}$ & $\begin{array}{l}-0.0442 \\
(0.0895)\end{array}$ & $\begin{array}{l}-0.0421 \\
(0.0889)\end{array}$ & $\begin{array}{l}-0.0429 \\
(0.0906)\end{array}$ \\
\hline Availability of blood-testing equipment & $\begin{array}{l}0.303^{* * *} \\
(0.0569)\end{array}$ & $\begin{array}{l}0.302^{* * *} \\
(0.0572)\end{array}$ & $\begin{array}{l}0.303^{* * *} \\
(0.0572)\end{array}$ & $\begin{array}{l}0.308^{* * *} \\
(0.0572)\end{array}$ \\
\hline Availability of urine-testing equipment & $\begin{array}{l}-0.119 \\
(0.114)\end{array}$ & $\begin{array}{l}-0.125 \\
(0.115)\end{array}$ & $\begin{array}{l}-0.123 \\
(0.114)\end{array}$ & $\begin{array}{l}-0.114 \\
(0.116)\end{array}$ \\
\hline Waiting time to get patient card & $\begin{array}{l}-0.00111 \\
(0.00450)\end{array}$ & $\begin{array}{l}-0.00125 \\
(0.00450)\end{array}$ & $\begin{array}{l}-0.00104 \\
(0.00450)\end{array}$ & $\begin{array}{l}-0.00138 \\
(0.00449)\end{array}$ \\
\hline Waiting time to see a medical professional & $\begin{array}{c}-0.00521^{* *} \\
(0.00216)\end{array}$ & $\begin{array}{c}-0.00531^{* *} \\
(0.00217)\end{array}$ & $\begin{array}{c}-0.00531^{* *} \\
(0.00217) \\
\text { (continued o }\end{array}$ & $\begin{array}{c}-0.00515^{* *} \\
(0.00216) \\
\text { n next page) }\end{array}$ \\
\hline
\end{tabular}


Table 7 (continued)

\begin{tabular}{|c|c|c|c|c|}
\hline Variables & Model 1 & Model 2 & Model 3 & Model 4 \\
\hline Perceived quality of care & $\begin{array}{l}0.194^{* * *} \\
(0.0604)\end{array}$ & $\begin{array}{l}0.195^{* * *} \\
(0.0597)\end{array}$ & $\begin{array}{l}0.194^{* * *} \\
(0.0603)\end{array}$ & $\begin{array}{l}0.190^{* * *} \\
(0.0605)\end{array}$ \\
\hline \multicolumn{5}{|l|}{ Community characteristics } \\
\hline Region-Tigray (ref: SNNPR) & $\begin{array}{l}0.0228 \\
(0.125)\end{array}$ & $\begin{array}{l}0.0242 \\
(0.123)\end{array}$ & $\begin{array}{l}0.0278 \\
(0.123)\end{array}$ & $\begin{array}{l}0.0225 \\
(0.124)\end{array}$ \\
\hline Region-Amhara & $\begin{array}{c}0.169 \\
(0.117)\end{array}$ & $\begin{array}{c}0.169 \\
(0.116)\end{array}$ & $\begin{array}{c}0.173 \\
(0.116)\end{array}$ & $\begin{array}{c}0.171 \\
(0.117)\end{array}$ \\
\hline Region-Oromiya & $\begin{array}{l}0.203^{*} \\
(0.119)\end{array}$ & $\begin{array}{c}0.207^{*} \\
(0.118)\end{array}$ & $\begin{array}{c}0.207^{*} \\
(0.118)\end{array}$ & $\begin{array}{l}0.213^{*} \\
(0.120)\end{array}$ \\
\hline Observations & 1,186 & 1,188 & 1,186 & 1,188 \\
\hline Pseudo $R$-squared & 0.1924 & 0.1926 & 0.1931 & 0.1970 \\
\hline Log pseudo likelihood & -641.088 & -642.061 & 640.503 & -638.523 \\
\hline
\end{tabular}

Notes: Outcome variable is CBHI enrollment status in 2012 and all explanatory variables are at their baseline (2011) values; clustered standard errors in parentheses; ${ }^{* * *} p<0.01,{ }^{* *} p<0.05,{ }^{*} p<0.1$.

\section{APPENDIX C}

Table 8. Probability of enrollment-marginal effects (std. error) (Excluding non-fee paying and households pressured to join the scheme)

\begin{tabular}{|c|c|c|c|c|}
\hline Variables & Model 1 & Model 2 & Model 3 & Model 4 \\
\hline \multicolumn{5}{|l|}{ Socioeconomic status } \\
\hline 2nd consumption quintile (ref: poorest consumption quintile) & $\begin{array}{l}0.00261 \\
(0.0498)\end{array}$ & $\begin{array}{c}0.00706 \\
(0.0509)\end{array}$ & $\begin{array}{l}0.00482 \\
(0.0502)\end{array}$ & $\begin{array}{l}0.00836 \\
(0.0510)\end{array}$ \\
\hline 3rd consumption quintile & $\begin{array}{c}0.0467 \\
(0.0526)\end{array}$ & $\begin{array}{c}0.0545 \\
(0.0541)\end{array}$ & $\begin{array}{c}0.0495 \\
(0.0532)\end{array}$ & $\begin{array}{c}0.0561 \\
(0.0540)\end{array}$ \\
\hline 4th consumption quintile & $\begin{array}{c}0.0457 \\
(0.0543)\end{array}$ & $\begin{array}{c}0.0448 \\
(0.0537)\end{array}$ & $\begin{array}{c}0.0447 \\
(0.0541)\end{array}$ & $\begin{array}{c}0.0439 \\
(0.0539)\end{array}$ \\
\hline Richest consumption quintile & $\begin{array}{c}0.0878 \\
(0.0738)\end{array}$ & $\begin{array}{c}0.0892 \\
(0.0752)\end{array}$ & $\begin{array}{c}0.0868 \\
(0.0745)\end{array}$ & $\begin{array}{c}0.0909 \\
(0.0734)\end{array}$ \\
\hline HH head education-Informal (ref: no education at all) & $\begin{array}{c}0.00498 \\
(0.0512)\end{array}$ & $\begin{array}{c}0.00328 \\
(0.0508)\end{array}$ & $\begin{array}{l}0.00294 \\
(0.0512)\end{array}$ & $\begin{array}{c}-0.00115 \\
(0.0505)\end{array}$ \\
\hline HH head education-Primary or above & $\begin{array}{c}0.0384 \\
(0.0452)\end{array}$ & $\begin{array}{c}0.0400 \\
(0.0452)\end{array}$ & $\begin{array}{c}0.0376 \\
(0.0450)\end{array}$ & $\begin{array}{c}0.0335 \\
(0.0454)\end{array}$ \\
\hline Participated in PSNP & $\begin{array}{l}0.288^{* * *} \\
(0.0703)\end{array}$ & $\begin{array}{l}0.292^{* * *} \\
(0.0703)\end{array}$ & $\begin{array}{l}0.288^{* * *} \\
(0.0699)\end{array}$ & $\begin{array}{l}0.301^{* * *} \\
(0.0702)\end{array}$ \\
\hline \multicolumn{5}{|l|}{ Demographic traits } \\
\hline Male-headed HH & $\begin{array}{c}0.0333 \\
(0.0530)\end{array}$ & $\begin{array}{c}0.0344 \\
(0.0520)\end{array}$ & $\begin{array}{c}0.0328 \\
(0.0527)\end{array}$ & $\begin{array}{c}0.0360 \\
(0.0517)\end{array}$ \\
\hline Age of HH head & $\begin{array}{l}0.000382 \\
(0.00175)\end{array}$ & $\begin{array}{l}0.000296 \\
(0.00175)\end{array}$ & $\begin{array}{l}0.000345 \\
(0.00174)\end{array}$ & $\begin{array}{c}0.000384 \\
(0.00178)\end{array}$ \\
\hline Household size & $\begin{array}{c}0.0243^{* *} \\
(0.00970)\end{array}$ & $\begin{array}{c}0.0241^{* *} \\
(0.00980)\end{array}$ & $\begin{array}{c}0.0241^{* *} \\
(0.00984)\end{array}$ & $\begin{array}{c}0.0225^{* *} \\
(0.00984)\end{array}$ \\
\hline Prop. of children aged under 6 (ref: Prop. of male aged 16-64) & $\begin{array}{l}-0.115 \\
(0.165)\end{array}$ & $\begin{array}{l}-0.124 \\
(0.164)\end{array}$ & $\begin{array}{l}-0.120 \\
(0.164)\end{array}$ & $\begin{array}{c}-0.0879 \\
(0.168)\end{array}$ \\
\hline Prop. of male aged $6-15$ & $\begin{array}{c}-0.0427 \\
(0.165)\end{array}$ & $\begin{array}{c}-0.0428 \\
(0.164)\end{array}$ & $\begin{array}{c}-0.0448 \\
(0.164)\end{array}$ & $\begin{array}{c}-0.0195 \\
(0.164)\end{array}$ \\
\hline Prop. of female aged $6-15$ & $\begin{array}{l}0.0980 \\
(0.161)\end{array}$ & $\begin{array}{l}0.0919 \\
(0.158)\end{array}$ & $\begin{array}{l}0.0879 \\
(0.161)\end{array}$ & $\begin{array}{c}0.112 \\
(0.159)\end{array}$ \\
\hline Prop. of female aged $16-64$ & $\begin{array}{l}-0.117 \\
(0.172)\end{array}$ & $\begin{array}{l}-0.123 \\
(0.173)\end{array}$ & $\begin{array}{l}-0.121 \\
(0.172)\end{array}$ & $\begin{array}{l}-0.102 \\
(0.171)\end{array}$ \\
\hline Prop. of elderly aged above 64 & $\begin{array}{l}-0.225 \\
(0.159)\end{array}$ & $\begin{array}{l}-0.210 \\
(0.157)\end{array}$ & $\begin{array}{l}-0.225 \\
(0.157)\end{array}$ & $\begin{array}{l}-0.199 \\
(0.165)\end{array}$ \\
\hline HH head religion—Orthodox Christian (ref: Muslim) & $\begin{array}{c}0.0903 \\
(0.0720)\end{array}$ & $\begin{array}{c}0.0875 \\
(0.0719)\end{array}$ & $\begin{array}{c}0.0909 \\
(0.0723)\end{array}$ & $\begin{array}{c}0.0987 \\
(0.0720)\end{array}$ \\
\hline HH head religion-Protestant & $\begin{array}{l}0.0569 \\
(0.105)\end{array}$ & $\begin{array}{l}0.0536 \\
(0.106)\end{array}$ & $\begin{array}{l}0.0584 \\
(0.105)\end{array}$ & $\begin{array}{l}0.0607 \\
(0.106)\end{array}$ \\
\hline $\mathrm{HH}$ head religion-Other religion or no religion & $\begin{array}{c}-0.0959 \\
(0.110)\end{array}$ & $\begin{array}{l}-0.102 \\
(0.106)\end{array}$ & $\begin{array}{c}-0.0980 \\
(0.108)\end{array}$ & $\begin{array}{c}-0.0800 \\
(0.113)\end{array}$ \\
\hline $\begin{array}{l}\text { Health status and health care use } \\
\text { Prop. of household members with poor SAH (ref: Prop. of household members with good SAH) }\end{array}$ & $\begin{array}{l}-0.0387 \\
(0.0532)\end{array}$ & $\begin{array}{l}-0.0482 \\
(0.0512)\end{array}$ & $\begin{array}{l}-0.0415 \\
(0.0526)\end{array}$ & $\begin{array}{l}-0.0628 \\
(0.0509)\end{array}$ \\
\hline
\end{tabular}


Table 8 (continued)

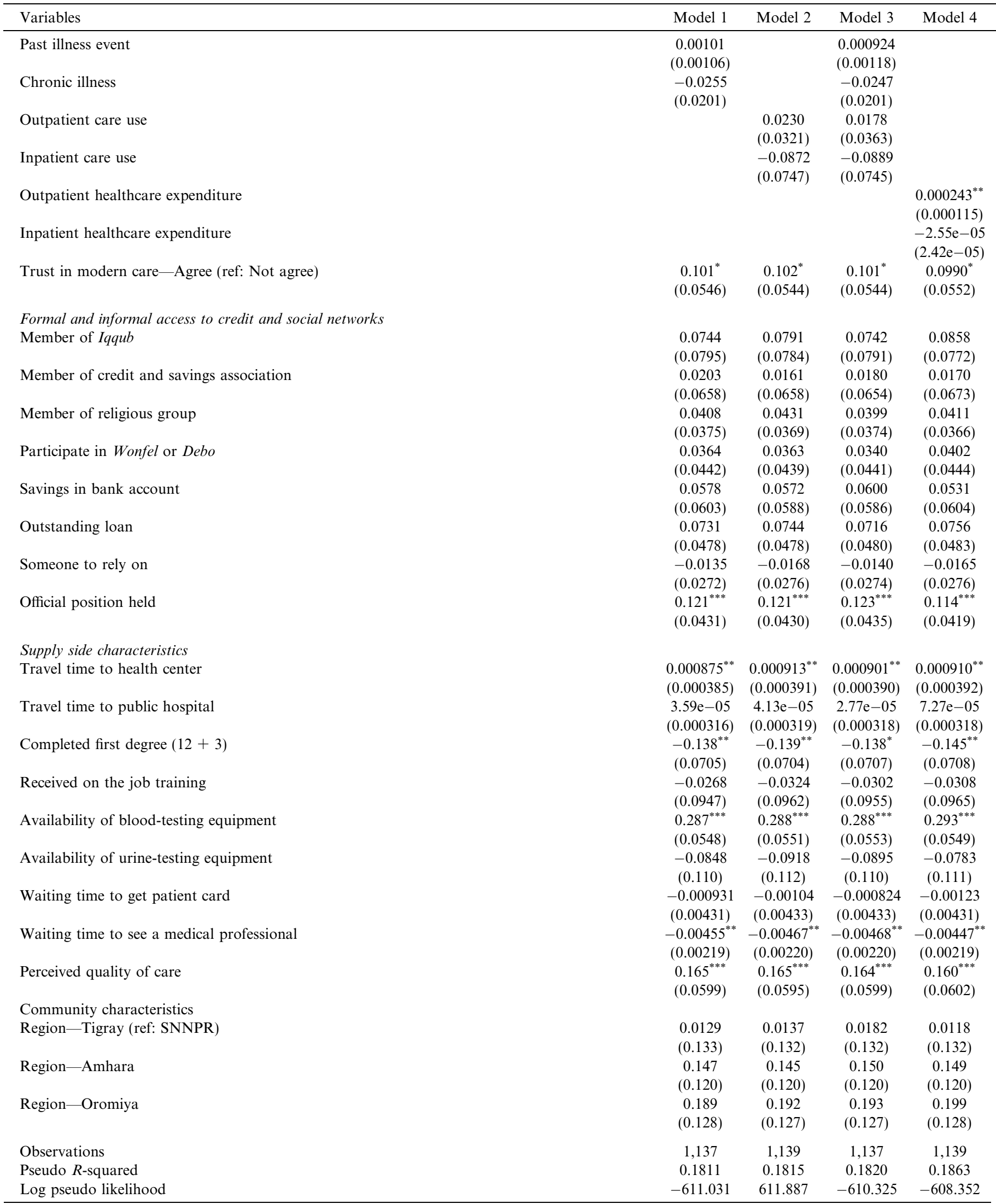

Notes: Outcome variable is CBHI enrollment status in 2012 and all explanatory variables are at their baseline (2011) values; clustered standard errors in parentheses; ${ }^{* * *} p<0.01,{ }^{* *} p<0.05,{ }^{*} p<0.1$. 
APPENDIX D

Table 9. Characteristics of target households per pilot region, 2011

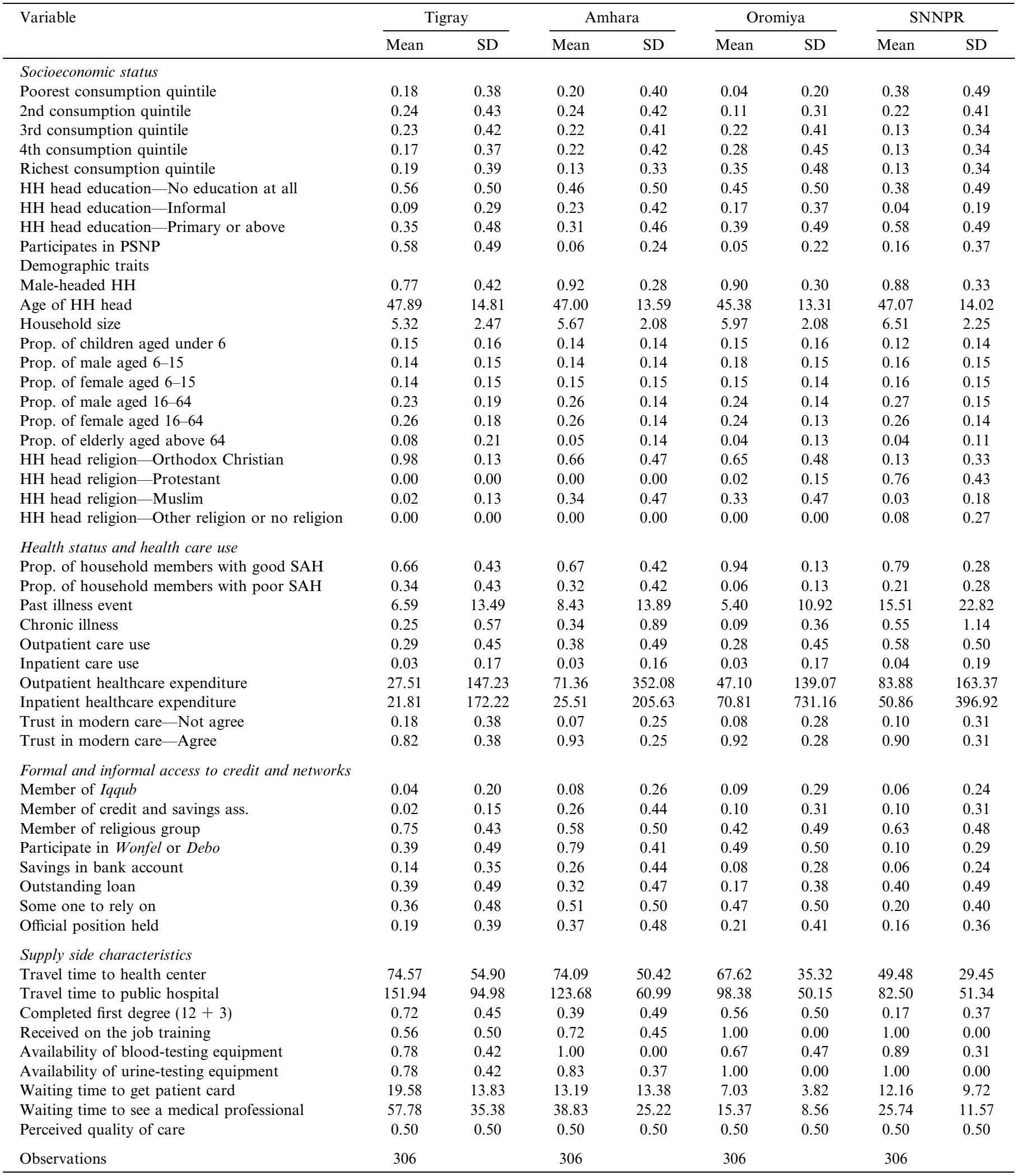


APPENDIX E

Table 10. Probability of enrollment-marginal effects (std. error) (Excluding regional dummies)

\begin{tabular}{|c|c|c|c|c|}
\hline Variables & Model 1 & Model 2 & Model 3 & Model 4 \\
\hline \multicolumn{5}{|l|}{ Socioeconomic status } \\
\hline 2nd consumption quintile (ref: poorest consumption quintile) & $\begin{array}{l}0.00639 \\
(0.0512)\end{array}$ & $\begin{array}{c}0.0111 \\
(0.0520)\end{array}$ & $\begin{array}{l}0.00844 \\
(0.0514)\end{array}$ & $\begin{array}{c}0.0118 \\
(0.0522)\end{array}$ \\
\hline 3rd consumption quintile & $\begin{array}{c}0.0262 \\
(0.0501)\end{array}$ & $\begin{array}{c}0.0341 \\
(0.0510)\end{array}$ & $\begin{array}{c}0.0282 \\
(0.0505)\end{array}$ & $\begin{array}{c}0.0353 \\
(0.0512)\end{array}$ \\
\hline 4th consumption quintile & $\begin{array}{c}0.0418 \\
(0.0501)\end{array}$ & $\begin{array}{c}0.0424 \\
(0.0496)\end{array}$ & $\begin{array}{c}0.0417 \\
(0.0502)\end{array}$ & $\begin{array}{c}0.0407 \\
(0.0498)\end{array}$ \\
\hline Richest consumption quintile & $\begin{array}{c}0.0961 \\
(0.0648)\end{array}$ & $\begin{array}{c}0.100 \\
(0.0654)\end{array}$ & $\begin{array}{c}0.0967 \\
(0.0650)\end{array}$ & $\begin{array}{c}0.101 \\
(0.0654)\end{array}$ \\
\hline HH head education-Informal (ref: no education at all) & $\begin{array}{c}0.0171 \\
(0.0518)\end{array}$ & $\begin{array}{c}0.0156 \\
(0.0514)\end{array}$ & $\begin{array}{c}0.0158 \\
(0.0518)\end{array}$ & $\begin{array}{c}0.0108 \\
(0.0508)\end{array}$ \\
\hline HH head education-Primary or above & $\begin{array}{c}0.0279 \\
(0.0453)\end{array}$ & $\begin{array}{c}0.0298 \\
(0.0453)\end{array}$ & $\begin{array}{c}0.0274 \\
(0.0453)\end{array}$ & $\begin{array}{c}0.0240 \\
(0.0454)\end{array}$ \\
\hline Participated in PSNP & $\begin{array}{l}0.257^{* * *} \\
(0.0582)\end{array}$ & $\begin{array}{l}0.261^{* * *} \\
(0.0584)\end{array}$ & $\begin{array}{l}0.257^{* * *} \\
(0.0582)\end{array}$ & $\begin{array}{l}0.265^{* * *} \\
(0.0580)\end{array}$ \\
\hline \multicolumn{5}{|l|}{ Demographic traits } \\
\hline Male-headed HH & $\begin{array}{c}0.0393 \\
(0.0515)\end{array}$ & $\begin{array}{c}0.0415 \\
(0.0500)\end{array}$ & $\begin{array}{c}0.0393 \\
(0.0510)\end{array}$ & $\begin{array}{c}0.0422 \\
(0.0501)\end{array}$ \\
\hline Age of HH head & $\begin{array}{l}0.000727 \\
(0.00179)\end{array}$ & $\begin{array}{l}0.000688 \\
(0.00178)\end{array}$ & $\begin{array}{l}0.000708 \\
(0.00178)\end{array}$ & $\begin{array}{c}0.000759 \\
(0.00179)\end{array}$ \\
\hline Household size & $\begin{array}{c}0.0196^{* *} \\
(0.00951)\end{array}$ & $\begin{array}{c}0.0195^{* *} \\
(0.00957)\end{array}$ & $\begin{array}{c}0.0195^{* *} \\
(0.00965)\end{array}$ & $\begin{array}{c}0.0181^{*} \\
(0.00974)\end{array}$ \\
\hline Prop. of children aged under 6 (ref: Prop. of male aged 16-64) & $\begin{array}{c}-0.0759 \\
(0.177)\end{array}$ & $\begin{array}{c}-0.0862 \\
(0.177)\end{array}$ & $\begin{array}{c}-0.0798 \\
(0.176)\end{array}$ & $\begin{array}{c}-0.0534 \\
(0.180)\end{array}$ \\
\hline Prop. of male aged 6-15 & $\begin{array}{l}0.0350 \\
(0.162)\end{array}$ & $\begin{array}{l}0.0355 \\
(0.163)\end{array}$ & $\begin{array}{l}0.0335 \\
(0.162)\end{array}$ & $\begin{array}{l}0.0568 \\
(0.162)\end{array}$ \\
\hline Prop. of female aged $6-15$ & $\begin{array}{c}0.141 \\
(0.164)\end{array}$ & $\begin{array}{c}0.138 \\
(0.161)\end{array}$ & $\begin{array}{c}0.133 \\
(0.163)\end{array}$ & $\begin{array}{c}0.154 \\
(0.163)\end{array}$ \\
\hline Prop. of female aged 16-64 & $\begin{array}{l}0.0750 \\
(0.201)\end{array}$ & $\begin{array}{l}0.0699 \\
(0.202)\end{array}$ & $\begin{array}{l}0.0720 \\
(0.200)\end{array}$ & $\begin{array}{l}0.0890 \\
(0.201)\end{array}$ \\
\hline Prop. of elderly aged above 64 & $\begin{array}{l}-0.174 \\
(0.158)\end{array}$ & $\begin{array}{l}-0.162 \\
(0.156)\end{array}$ & $\begin{array}{l}-0.174 \\
(0.157)\end{array}$ & $\begin{array}{l}-0.152 \\
(0.161)\end{array}$ \\
\hline HH head religion-Orthodox Christian (ref: Muslim) & $\begin{array}{c}0.0760 \\
(0.0718)\end{array}$ & $\begin{array}{c}0.0725 \\
(0.0715)\end{array}$ & $\begin{array}{c}0.0760 \\
(0.0720)\end{array}$ & $\begin{array}{c}0.0805 \\
(0.0710)\end{array}$ \\
\hline HH head religion-Protestant & $\begin{array}{l}-0.0557 \\
(0.0825)\end{array}$ & $\begin{array}{l}-0.0575 \\
(0.0825)\end{array}$ & $\begin{array}{l}-0.0565 \\
(0.0836)\end{array}$ & $\begin{array}{l}-0.0549 \\
(0.0807)\end{array}$ \\
\hline HH head religion-Other religion or no religion & $\begin{array}{c}-0.172^{*} \\
(0.103)\end{array}$ & $\begin{array}{l}-0.176^{*} \\
(0.0988)\end{array}$ & $\begin{array}{c}-0.175^{*} \\
(0.101)\end{array}$ & $\begin{array}{l}-0.161 \\
(0.103)\end{array}$ \\
\hline \multicolumn{5}{|l|}{ Health status and health care use } \\
\hline Prop. of household members with poor SAH (ref: Prop. of household members with good SAH) & $\begin{array}{l}-0.0455 \\
(0.0579)\end{array}$ & $\begin{array}{l}-0.0530 \\
(0.0565)\end{array}$ & $\begin{array}{l}-0.0474 \\
(0.0573)\end{array}$ & $\begin{array}{l}-0.0653 \\
(0.0572)\end{array}$ \\
\hline Past illness event & $\begin{array}{c}0.00126 \\
(0.00107)\end{array}$ & & $\begin{array}{c}0.00120 \\
(0.00120)\end{array}$ & \\
\hline Chronic illness & $\begin{array}{l}-0.0274 \\
(0.0220)\end{array}$ & & $\begin{array}{l}-0.0267 \\
(0.0220)\end{array}$ & \\
\hline Outpatient care use & & $\begin{array}{c}0.0211 \\
(0.0329)\end{array}$ & $\begin{array}{c}0.0124 \\
(0.0376)\end{array}$ & \\
\hline Inpatient care use & & $\begin{array}{l}-0.0576 \\
(0.0871)\end{array}$ & $\begin{array}{l}-0.0618 \\
(0.0863)\end{array}$ & \\
\hline Outpatient healthcare expenditure & & & & $\begin{array}{l}0.000219^{* *} \\
(0.000109)\end{array}$ \\
\hline Inpatient healthcare expenditure & & & & $\begin{array}{l}-1.89 \mathrm{e}-05 \\
(2.59 \mathrm{e}-05)\end{array}$ \\
\hline Trust in modern care-Agree (ref: Not agree) & $\begin{array}{c}0.104^{* *} \\
(0.0521)\end{array}$ & $\begin{array}{c}0.105^{* *} \\
(0.0517)\end{array}$ & $\begin{array}{c}0.104^{* *} \\
(0.0519)\end{array}$ & $\begin{array}{l}0.104^{* *} \\
(0.0525)\end{array}$ \\
\hline \multicolumn{5}{|l|}{ Formal and informal access to credit and social networks } \\
\hline Member of Iqqub & $\begin{array}{c}0.0601 \\
(0.0776)\end{array}$ & $\begin{array}{c}0.0653 \\
(0.0765)\end{array}$ & $\begin{array}{c}0.0599 \\
(0.0774)\end{array}$ & $\begin{array}{c}0.0714 \\
(0.0758)\end{array}$ \\
\hline
\end{tabular}


Table 10 (continued)

\begin{tabular}{|c|c|c|c|c|}
\hline Variables & Model 1 & Model 2 & Model 3 & Model 4 \\
\hline Member of credit and savings association & $\begin{array}{c}0.0676 \\
(0.0644)\end{array}$ & $\begin{array}{c}0.0643 \\
(0.0639)\end{array}$ & $\begin{array}{c}0.0659 \\
(0.0637)\end{array}$ & $\begin{array}{c}0.0666 \\
(0.0653)\end{array}$ \\
\hline Member of religious group & $\begin{array}{c}0.0113 \\
(0.0382)\end{array}$ & $\begin{array}{c}0.0136 \\
(0.0372)\end{array}$ & $\begin{array}{c}0.0104 \\
(0.0378)\end{array}$ & $\begin{array}{c}0.0115 \\
(0.0373)\end{array}$ \\
\hline Participate in Wonfel or Debo & $\begin{array}{c}0.0766^{*} \\
(0.0412)\end{array}$ & $\begin{array}{l}0.0767^{*} \\
(0.0411)\end{array}$ & $\begin{array}{c}0.0752^{*} \\
(0.0415)\end{array}$ & $\begin{array}{l}0.0810^{*} \\
(0.0415)\end{array}$ \\
\hline Savings in bank account & $\begin{array}{c}0.0477 \\
(0.0585)\end{array}$ & $\begin{array}{c}0.0460 \\
(0.0575)\end{array}$ & $\begin{array}{c}0.0490 \\
(0.0572)\end{array}$ & $\begin{array}{c}0.0431 \\
(0.0586)\end{array}$ \\
\hline Outstanding loan & $\begin{array}{c}0.0477 \\
(0.0482)\end{array}$ & $\begin{array}{c}0.0494 \\
(0.0481)\end{array}$ & $\begin{array}{c}0.0468 \\
(0.0483)\end{array}$ & $\begin{array}{c}0.0498 \\
(0.0489)\end{array}$ \\
\hline Someone to rely on & $\begin{array}{l}-0.0145 \\
(0.0294)\end{array}$ & $\begin{array}{l}-0.0186 \\
(0.0297)\end{array}$ & $\begin{array}{l}-0.0148 \\
(0.0296)\end{array}$ & $\begin{array}{l}-0.0185 \\
(0.0297)\end{array}$ \\
\hline Official position held & $\begin{array}{l}0.117^{* * *} \\
(0.0407)\end{array}$ & $\begin{array}{l}0.116^{* * *} \\
(0.0403)\end{array}$ & $\begin{array}{l}0.118^{* * *} \\
(0.0411)\end{array}$ & $\begin{array}{l}0.110^{* * *} \\
(0.0391)\end{array}$ \\
\hline Supply side characteristics & & & & \\
\hline Travel time to health center & $\begin{array}{l}0.000866^{* *} \\
(0.000390)\end{array}$ & $\begin{array}{l}0.000908^{* *} \\
(0.000391)\end{array}$ & $\begin{array}{l}0.000885^{* *} \\
(0.000393)\end{array}$ & $\begin{array}{l}0.000897^{* *} \\
(0.000396)\end{array}$ \\
\hline Travel time to public hospital & $\begin{array}{c}2.83 \mathrm{e}-05 \\
(0.000344)\end{array}$ & $\begin{array}{c}3.58 \mathrm{e}-05 \\
(0.000346)\end{array}$ & $\begin{array}{c}2.65 \mathrm{e}-05 \\
(0.000345)\end{array}$ & $\begin{array}{c}5.72 \mathrm{e}-05 \\
(0.000348)\end{array}$ \\
\hline Completed first degree $(12+3)$ & $\begin{array}{l}-0.0958 \\
(0.0659)\end{array}$ & $\begin{array}{l}-0.0961 \\
(0.0649)\end{array}$ & $\begin{array}{l}-0.0951 \\
(0.0657)\end{array}$ & $\begin{array}{l}-0.1000 \\
(0.0651)\end{array}$ \\
\hline Received on the job training & $\begin{array}{l}-0.0591 \\
(0.0872)\end{array}$ & $\begin{array}{l}-0.0635 \\
(0.0877)\end{array}$ & $\begin{array}{l}-0.0616 \\
(0.0873)\end{array}$ & $\begin{array}{l}-0.0621 \\
(0.0881)\end{array}$ \\
\hline Availability of blood-testing equipment & $\begin{array}{l}0.293^{* * *} \\
(0.0472)\end{array}$ & $\begin{array}{l}0.290^{* * *} \\
(0.0471)\end{array}$ & $\begin{array}{l}0.292^{* * *} \\
(0.0476)\end{array}$ & $\begin{array}{l}0.295^{* * *} \\
(0.0472)\end{array}$ \\
\hline Availability of urine-testing equipment & $\begin{array}{l}-0.104 \\
(0.100)\end{array}$ & $\begin{array}{l}-0.109 \\
(0.101)\end{array}$ & $\begin{array}{c}-0.108 \\
(0.0994)\end{array}$ & $\begin{array}{c}-0.0979 \\
(0.102)\end{array}$ \\
\hline Waiting time to get patient card & $\begin{array}{l}-0.00278 \\
(0.00442)\end{array}$ & $\begin{array}{l}-0.00296 \\
(0.00440)\end{array}$ & $\begin{array}{l}-0.00274 \\
(0.00441)\end{array}$ & $\begin{array}{l}-0.00316 \\
(0.00441)\end{array}$ \\
\hline Waiting time to see a medical professional & $\begin{array}{c}-0.00518^{* *} \\
(0.00212)\end{array}$ & $\begin{array}{c}-0.00526^{* *} \\
(0.00214)\end{array}$ & $\begin{array}{c}-0.00525^{* *} \\
(0.00213)\end{array}$ & $\begin{array}{c}-0.00510^{* *} \\
(0.00213)\end{array}$ \\
\hline Perceived quality of care & $\begin{array}{l}0.195^{* * *} \\
(0.0597)\end{array}$ & $\begin{array}{l}0.196^{* * *} \\
(0.0588)\end{array}$ & $\begin{array}{l}0.195^{* * *} \\
(0.0597)\end{array}$ & $\begin{array}{l}0.192^{* * *} \\
(0.0593)\end{array}$ \\
\hline Observations & 1,203 & 1,205 & 1,203 & 1,205 \\
\hline Pseudo $R$-squared & 0.1735 & 0.1731 & 0.1739 & 0.1768 \\
\hline Log pseudo likelihood & -669.122 & -670.599 & -668.806 & -667.597 \\
\hline
\end{tabular}

Notes: Outcome variable is CBHI enrollment status in 2012 and all explanatory variables are at their baseline (2011) values; clustered standard errors in parentheses; ${ }^{* * *} p<0.01,{ }^{* *} p<0.05,{ }^{*} p<0.1$. 